\title{
The Structure of Regional Original Revenue and Its Effect on Economic Growth: Facts from Regencies and Cities in Central Jawa
}

\author{
Wahyudi Susanto ${ }^{1}$ \\ Catur Sugiyanto ${ }^{2}$ \\ Gadjah Mada University - Indonesia
}

\begin{abstract}
This study aims to determine the structure of Regional Original Revenue (PAD) in its effect on economic growth. The data used are panel data from 35 regencies and cities in Central Java for the period 2005 to 2015. Data are taken from the Regencies and Cities Financial Audit Results Reports in Central Java. Data analysis technique uses Panel Vector Error Correction Model (PVECM) and Panel Granger Causality Test to determine the relationship between economic growth and PAD components, namely regional tax revenue, regional retribution revenue, regional wealth revenue and other legitimate revenue. The results of this study found a one-way causality relationship from tax revenue to economic growth. There is a two-way relationship occurs between retribution revenue and economic growth. There is a one-way relationship from the regional wealth revenue to economic growth. There is a one-way relationship from the total regional original revenue (PAD) to economic growth. There is no relationship between other legitimate revenue and economic growth. In the short run, the economic growth over a given period was positively and significantly affected by the tax revenue, retribution revenue and regional original revenue (PAD) of the previous year, while regional wealth revenue has a negative and significant affect on economic growth. In the long run, tax revenue, retribution revenue and regional original revenue (PAD) affect by positively and significantly to economic growth, while regional wealth revenue has a negative and significant affect on economic growth.
\end{abstract}

Keywords: Regional Original Revenue (PAD), Economic Growth, Granger Causality Test, Panel Vector Error Correction Model (PVECM).

\footnotetext{
${ }^{1}$ Wahyudi Susanto is a Student of Master of Economics of Development Program, Faculty of Economics and Business, Gadjah Mada University. E-mail: wahyudi.susanto@gmail.com ${ }^{2}$ Catur Sugianto is a Lecturer of Master of Economics of Development Program, Faculty of Economics and Business, Gadjah Mada University. E-mail: catur@ugm.ac.id
} 


\section{The Structure of Regional Original Revenue and Its Affect on Economic Growth: Facts from Regencies and Cities in Central Jawa \\ Wahyudi Susanto and Catur Sugiyanto}

\section{Introduction}

Based on MPR Decree No. XV/MPR/1998 dated January 1, 2001 the Government of the Republic of Indonesia officially declared the commencement of the implementation of regional autonomy. Regional autonomy based on Law Number 22 of 1999 is more of a decentralized nuance, in which regions are close as separate autonomous regions, which use the central government delegated to the governor.

Fiscal decentralization is the delegation of authority to the regions to manage their own financial resources, so that regions have more opportunities to regulate their households. The basic principle of implementing fiscal decentralization in Indonesia is "Money Follows Functions", which is the main function of public services delivered, by submitting sources of revenue to the regions (Siagian 2010, 3).

The sources of regional revenue in the form of Regional Original Revenue (PAD) and transfers (General Allocation Funds, Revenue Sharing Funds, Special Allocation Funds and Autonomy Funds) are expected to increase economic growth and improve the welfare of people in the area. Economic growth is an increase in revenue to the amount of the value of goods and services produced by an economy within one year (Hubbard dkk. 2014, 32).

Figure 1. Comparison of Central Java's Economic Growth with Indonesia

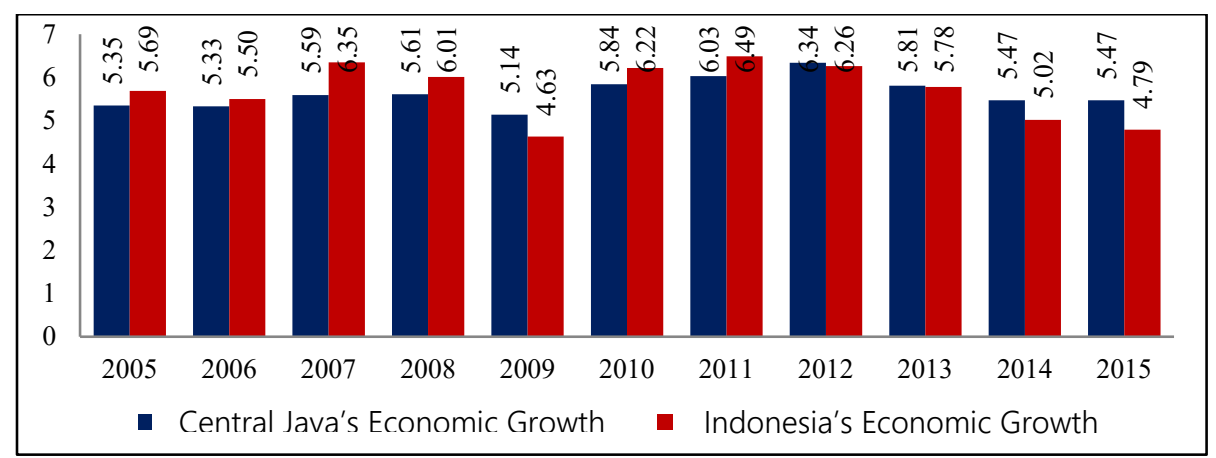

Source: Berita Resmi Statistik BPS, 2017

Economic growth in Central Java averages 5,47\% and is always below national economic growth in the 2005-2010 period. In the 2011-2015 period, the opposite applies, economic growth in Central Java on average remained at 
$5,82 \%$ as shown in Figure 1. This indicates that economic growth in Central Java is able to sustain national economic growth.

Figure 2. Comparison of Central Java's economic growth with PAD growth in regencies and cities in Central Java

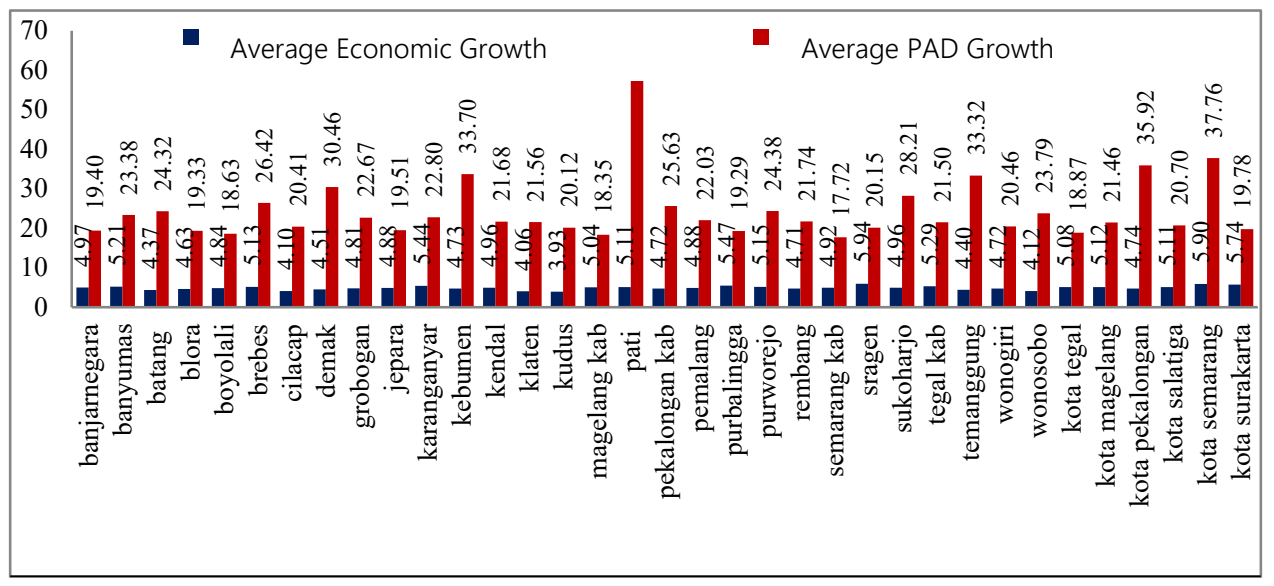

Source: Official Publication of BPS and BPK, 2017

Factors that foster the economy include ownership of natural resources, people population, labor and technology. The economy of the Central Java region is interrelated because of the transportation system. Therefore, an analysis of the relationship between PAD and regional economic growth in Central Java must be done by panel analysis.

In Figure 2, economic growth in regencies and cities in Central Java is relatively stable on average at $4,90 \%$ in the period $2005-2015$. PAD growth is relatively fluctuating and on average is always above economic growth, which is $24 \%$. Based on this, it seems that PAD has nothing to do with economic growth.

An empirical study of the relationship between tax and economic growth is still not conclusive. Some studies prove the positive affect of tax on economic growth including Easterly and Rebelo (1993), limi (2005), Arnold (2008), Hammond and Tosun (2009), Myles (2009), Xing (2011), Bacarreza, Vazquez, and Vulovic (2013), Bujang, Hakim, and Ahmad (2013), Stoilova and Patonov (2013), Szarowska (2013), Devkota (2014), Mutiara (2015), Takumah and lyke (2015), Saidin, Basit, and Hamza (2016), as well as Stoilova (2017). Studies that proves the positive affect of tax on economic growth states that increasing tax revenues will directly increase government revenues.

On the other hand, other researchers also prove the negative affect of tax on economic growth including Sugiyanto (1995), Davoodi and Zou (1998), Kneller, Bleaney, and Gemmell (1999), Widmalm (2001), Folster and Henrekson (2001), Lee and Gordon (2004), Bodman, Heaton, and Hodge (2009), Pose and Krøijer (2009), Pose and Ezcurra (2010), Gemmell, Kneller, and Sanz (2013), 
Anicic, Jelic, and Durovic (2015), Paparas and Richter (2015), Yushkov (2015) and Vatamanu and Oprea (2017). Studies that proves the negative affect of tax on economic growth states that relatively high taxes will reduce public consumption and investment.

Studies that state a negative relationship between economic growth and tax are found by Taha, Loganathan, and Colombage (2011) and Triastuti and Pratomo (2016). These studies state that economic growth is increasing because of reduced tax collection on the community which causes the level of consumption and investment to rise, thus increasing GDP.

Retribution is proven to encourage economic growth because the function of retribution is one source of regional revenue that can be used for regional government spending which can increase GDP as the study results of Mutiara (2015) and Pattawe et al. (2017). Studies that shows that retribution has a negative effect on economic growth has not been found.

PAD is encouraging economic growth because PAD functions as one of the fiscal components of regional governments in equitable distribution of regional development and equitable distribution of revenue for local communities so as to facilitate economic activities and consumption that can increase GDP as studies result of Putri (2015), Hendriwiyanto (2016), Rori, Luntungan, and Niode (2016), Manek and Badrudin (2016) and Muti'ah (2017). On the other hand, studies that found a positive relationship of economic growth to PAD include Desmawati, Zamzani, and Zulgani (2015) and Susanti et al. (2017).

Economic growth and PAD are two key variables in the region. However, the relationship between the two variables is still not conclusive. On the one hand, the revenue of PAD is an engine that drives investment so that it can encourage economic growth. Similarly, economic growth is a source of PAD. On the other hand, PAD is also negative because the high revenue of PAD causes public consumption and investment to decline, while economic growth has a negative effect on PAD given the ineffectiveness of regional government spending in facilitating economic activity.

With the above conditions it is still unclear how the nature of the relationship between PAD and economic growth in Central Java Province. By knowing the conditions of the relationship between the PAD structure and economic growth, the Regional Government can formulate fiscal policies that will be taken to increase PAD and economic growth in Central Java.

Economic growth, taxes, retribution, regional wealth, other legitimate revenue and PAD are believed to be interrelated economic variables. However, the literature shows empirical differences in how the style of tax relations (as a 
source of PAD) with economic growth. Meanwhile, data on economic growth and PAD in Central Java seems unrelated during the period 2005-2015.

This study aims to determine the relationship between PAD and economic growth in regencies and cities in Central Java. The findings of this study are expected to help regional governments improve understanding of the nature of PAD relations and economic growth and take fiscal policies to maximize the PAD of their respective regions to advance the economy in their regions.

\section{Literature Review}

\subsection{Regional Government Original Revenue System in Indonesia}

Tax according to Law Number 28 of 2007 concerning Third Amendment to Law Number 6 of 1983 concerning General Provisions and Tax Procedures is a mandatory contribution to the state which is owed by an individual or an entity that is compulsory under the law, with no direct compensation and is used for the state's needs as much as possible for the people's prosperity.

Regional taxes consist of, among others, hotel tax, restaurant tax, entertainment tax, advertisement tax, street lighting tax, parking tax, groundwater tax, land and building tax, land acquisition rights and building tax. The central government has again issued regulations on regional taxes and regional retribution through Law Number 28 of 2009.

With this Law, Law Number 18 of 1997 was revoked as amended by Law Number 34 of 2000. Regional retribution includes, retribution on public services, cleaning services, funeral services, roadside parking, land rent, tera test, business service fees, terminals, licensing levies, permission to disturb and others.

Law Number 33 of 2004 classifies the types of results of regional wealth management that are separated, broken down according to the revenue object which includes part of the return on equity participation in Regional Owned Enterprises (BUMD), part of the return on equity participation in State Owned Enterprises (BUMN) and the return equity participation in privately owned companies or community groups. Among other legitimate revenue is the sale of unregistered regional wealth, the results of the utilization or utilization of regional assets that are not separated, current account services, interest revenue, compensation claims, profit from the difference between the rupiah exchange rate against foreign currencies and commissions, deductions or other forms as a result of the sale and / or procurement of goods and or services by the region.

According to Law Number 17 of 2003 Article 1 Letter 9 and Article 11 Paragraph 3 concerning State Finance, state revenues are all cash receipts that enter the state consisting of tax revenues and not taxes and grants. Tax revenue 
is also classified into two, namely tax revenue from the central and tax revenue from the region.

Regional tax revenues are cash receipts that go into the regional treasury collected by the regional government (in this case carried out by the Regional Revenue Service/Dispenda) which are used to finance the households of the regional government and are listed in the Regional Revenue and Expenditure Budget (APBD).

\subsection{Economic growth}

Understanding economic growth according to Todaro $(2006,45)$ is a process that causes changes in people's lives, namely political changes, social structures, social values and the structure of their economic activities. In addition, according to Arsyad $(1997,57)$ economic growth is a process that causes an increase in the per capita revenue of a country's population in the long run accompanied by an improvement in the institutional system.

Economic growth is often measured using growth of Gross Domestic Product (GDB/GRDB). Gross Regional Domestic Product (GRDP) basically is the amount of added value produced by all business units in a particular area, or is the sum of the value of the final goods and services produced by all economic units. Hubbard et al. $(2014,72)$ states that calculating real GDP uses a comparison of the year to base year and uses the base year price as the basis for calculating the value of goods and services during the calculated annual period.

\subsection{Relationship between $P A D$ and economic growth}

According to Saragih $(2003,15)$, an increase in PAD is actually an excess of regional economic growth whose positive economic growth is likely to get an increase in PAD. This perspective should make regional governments more concentrated on empowering local economic forces to create economic growth rather than simply issuing regulatory products related to taxes or retribution.

Increasing the economic growth of a region is also able to attract investors to invest in the region so that the sources of PAD, especially those from regional taxes, will increase. High PAD can then be used by regional governments to provide adequate public services so that this will increase capital expenditure. Such spending will increase aggregate expenditure and enhance economic activity.

As economic activity increases, the flow of government revenues through PAD also increases. Government expenditure reflects government policies to improve people's welfare. The government must provide public goods, because there is no private sector that wants to provide goods that people enjoy. Government activities will shift from providing facilities to expenditures for social activities which can ultimately increase economic activity. 
In this case, the regional government imposes regional tax and retribution so that PAD also increases.

\section{Method}

To make it easier to understand the strategy of this research, it can be described the following research design flowchart.

Figure 3. Research Design Diagram

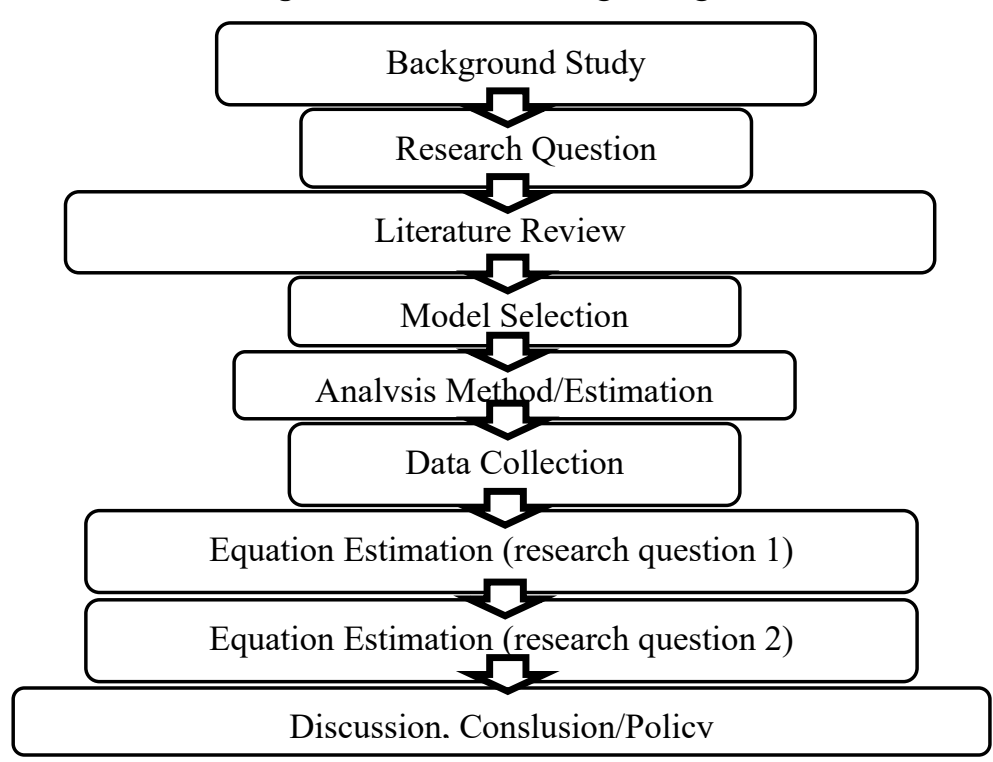

The data used in this study are panel data for the years 2005 to 2015 that are sourced from the Audit Report on the Financial Statements of Regencies and Cities Governments in Central Java that issued by the Republic of Indonesia Supreme Audit Agency.

According to Granger (1969), causality can be divided into two, namely long run and short run. Sims (1972), developed the VAR method to estimate short run and long run relationships between variables which can be formulated as follows:

$$
y_{i t}=\alpha_{i}+\beta_{1} y_{i t-1}+\ldots \ldots .+\beta_{k} y_{i t-k}+\epsilon_{i t}
$$

The model's initial equation is assumed to be a PVAR model used to describe the following causality relationships:

$$
\begin{aligned}
& Y_{i t}=\alpha_{0}+\alpha_{1} Y_{i t-1}+\alpha_{2} Y_{i t-n}+\beta_{1} X_{i t-1}+\beta_{2} X_{i t-n}+\mu_{i t} \\
& X_{i t}=\gamma_{0}+\gamma_{1} X_{i t-1}+\gamma_{2} X_{i t-n}+\delta_{1} Y_{i t-1}+\delta_{2} Y_{i t-n}+v_{i t}
\end{aligned}
$$

where: $Y=$ endogenous variable $1 ; X=$ endogenous variable 2 . 


\section{Panel Vector Auto Regression (PVAR) and Panel Vector Error Correction Model (PVECM)}

According to Dorsman et al. (2012), causality can be explained by the PVAR model at level I(1). Granger Causality Test can be done with the PVAR model by separating exogenity from the Wald Test. Long run relationships can be investigated using the Panel Vector Error Correction Model (PVECM) and the affect of short run relationships using the Wald Test. Use PVECM if the data form is not stationary at $\mathrm{I}(0)$ and cointegration occurs even though it is stationary at I(1). PVECM can restructure the long run relationship of endogenous variables in order to remain convergent into their cointegration relationship. The PVECM equation can be formulated as follows:

$$
\Delta y_{i t}=\delta d_{i t}+\alpha \beta_{1} y_{i t-1}+\Gamma X_{i t}+\epsilon_{i t}, \mathrm{t}=1,2,3, \ldots \mathrm{T}
$$

where: $\Delta y_{i t}=$ matrix difference $\mathrm{k}$ observed variable; $y_{i t-1}=$ matrix first lag observed variable; $\delta$ = parameter matrix of the model determinant component; $d_{i t}=$ vector determinant component to $\mathrm{t} ; \alpha \beta_{1}=$ long-run equation coefficient matrix; $\Gamma=$ dynamic matrix of short-run equations; $X_{i t}=$ matrix difference observed in lag $\mathrm{k}_{;} \epsilon_{i t}=$ matriks error term.

\section{Granger Causality Test}

This study will examine the direction of the relationship between economic growth variables with interest variables namely tax revenue, retribution revenue, regional wealth revenue, other legitimate revenue and PAD. Bernard and Willet (1996) state that there are at least two methods for determining the direction of relationships between variables. First, by testing causality statistically using the Granger Test. Second, by determining the direction of relations on an ad hoc basis based on the characteristics of the conditions formed, namely by looking at whether economic growth is often caused by changes in interest variables or interest variables more often caused by economic growth.

\section{Results and Discussion}

To facilitate the analysis and interpretation, the data analyzed will all be made into a percentage of the nominal real GDP of each region. Observation data analyzed amounted to 385 consisting of 35 regencies and cities in the 11year period (2005-2015). The following is a summary table of data that will be used in the research analysis: 
Table 1. Summary of Research Data

\begin{tabular}{lccccc}
\hline \multicolumn{1}{c}{ Variabel } & Obs. & Mean & Std. Dev. & Min & Max \\
\hline Economic growth (\%) & 385 & 4,9050 & 0,9246 & 1,53 & 7,72 \\
PAD (\%PDRB) & 385 & 3,1637 & 2,5324 & 0,3397 & 20,012 \\
Tax revenue (\%PDRB) & 385 & 0,7558 & 0,7122 & 0,055 & 5,5775 \\
Retribution revenue (\%PDRB) & 385 & 0,7942 & 0,6455 & 0,0746 & 8,5078 \\
Regional wealth revenue (\%PDRB) & 385 & 0,1519 & 0,1984 & 0,0059 & 3,4027 \\
Other legitimate revenue (\%PDRB) & 385 & 1,4615 & 1,9595 & 0,0158 & 18,7687 \\
\hline
\end{tabular}

Source: $L H P-L K P D$, be treated (BPK 2005-2015)

\section{Stationarity test}

As a first step in data analysis, it is necessary to do a unit root test on variables that are important variables in this study, namely economic growth variables, tax revenue, retribution revenue, regional wealth revenue, other legitimate revenue and PAD variables. Unit root testing uses the Augmented Dickey-Fuller Test (ADF) and Levine-Liu-Chu Test methods. The data is said to be stationary if the statistical test value is smaller than the critical value of at least $5 \%$ which is equal to $-2,8671$ and the probability value is smaller than 0,05 .

Data on economic growth at I(0) or data at the level indicates that there is no unit root because the statistical test value is $-4,6292$ and smaller than the critical level of $1 \%(-3,4433)$, so the data is said to be stationary. Data other than economic growth variables have unit roots because the test value is at a value greater than $-2,8671$. With these results, it is necessary to see first different level of PAD data, tax revenue, retribution revenue, regional wealth revenue, other legitimate revenue there are still units root or not.

Data testing shows that all data have no root units with statistical values greater than the critical level of $1 \%(-3,4443)$. So it can be concluded that all data to be used in this study are stationary at I(1). Granger and Newbold (1974), say that the non-stationary data will produce variable relationships that look statistically significant but in reality it is not or the relationship is not as big as the regression produced.

\section{Cointegration test}

Cointegration testing is used to determine the balance relationship intervariables in the long-run, in this case is the variable of economic growth and PAD. Cointegration testing using the Pedroni Residual Cointegration Test method is by comparing the probability values of seven panel categories. The seven panel categories are v-statistics panel, rho-statistics panel, PP-statistics panel, ADF-statistics panel, rho-statistical group, PP-statistical group and ADFstatistical group. If the probability value of the seven criteria is smaller than 0.05 , the null hypothesis that economic growth and PAD do not have cointegration 
cannot be rejected. Conversely, if the probability value is greater than 0.05 , the null hypothesis can be rejected.

Table 2. Cointegration Test Results Using Pedroni Residual Cointegration Test at $I(0)$ and $I(1)$

\begin{tabular}{lcc}
\hline \multicolumn{1}{c}{ Cointegration test variables } & $\mathrm{I}(0)$ & $\mathrm{I}(1)$ \\
\hline Economic growth and tax revenue & cointegrated & cointegrated \\
Economic growth and retribution revenue & cointegrated & cointegrated \\
cointegrated & cointegrated \\
revenue & & \\
$\begin{array}{l}\text { Economic growth and other legitimate } \\
\text { revenue }\end{array}$ & cointegrated & cointegrated \\
Economic growth and PAD & cointegrated & cointegrated \\
\hline Source: $L H P$ - $L K P D$, be treated (BPK 2005-2015) & &
\end{tabular}

The test results in Table 2, cointegration occurs in both testing models on data level/I(0) and at I(1). Therefore, the analysis continued with PVECM. This is because both variables occur long run relationships, while PVAR requires that no cointegration between variables will be estimated.

\section{Optimal lag selection}

According to Amri (2017), the optimal choice of lag is used to determine the time period of the influence of a variable on other variables optimally. Knowledge of optimal lag is due to the affect of changing a variable on other variables does not always occur in the same time period.

Table 3. Optimal Lag Selection Results

\begin{tabular}{|c|c|c|c|c|c|c|}
\hline Lag & LogL & $L R$ & FPE & $\mathrm{AIC}$ & SC & $\mathrm{HQ}$ \\
\hline \multicolumn{7}{|c|}{ Economic growth and tax revenue } \\
\hline 0 & $-4,4924$ & NA & 0,0860 & 3,2231 & 3,2491 & 3,2335 \\
\hline 1 & $-4,0612$ & 8,5312 & 0,0650 & 2,9437 & $3,0216^{*}$ & 2,9749 \\
\hline 2 & $-3,9531$ & $21,2443^{*}$ & $0,0619^{*}$ & $2,8950^{*}$ & 3,0248 & $2,9471^{*}$ \\
\hline \multicolumn{7}{|c|}{ Economic growth and retribution revenue } \\
\hline 0 & $-7,0114$ & NA & 0,5203 & 5,0224 & 5,0484 & 5,0329 \\
\hline 1 & $-6,1639$ & 1,6768 & 0,2922 & 4,4457 & 4,5236 & 4,4769 \\
\hline 2 & $-6,0373$ & $24,869^{\star}$ & $0,2747^{*}$ & $4,3838^{\star}$ & $4,5136^{*}$ & $4,4359 *$ \\
\hline \multicolumn{7}{|c|}{ Economic growth and regional wealth revenue } \\
\hline 0 & $-3,9712$ & NA & 0,0593 & 2,8508 & 2,8768 & 2,8612 \\
\hline 1 & $-2,7976$ & 2,3219 & 0,0263 & 2,0412 & 2,1191 & 2,0724 \\
\hline 2 & $-2,6825$ & $22,6112^{\star}$ & $0,0250^{\star}$ & $1,9875^{*}$ & $2,1173^{*}$ & $2,0396 *$ \\
\hline \multicolumn{7}{|c|}{ Economic growth and other legitimate revenue } \\
\hline 0 & $-9,1373$ & NA & 2,3755 & 6,5409 & 6,5669 & 6,5514 \\
\hline 1 & $-8,4799$ & 1,3007 & 1,5284 & 6,0999 & 6,1778 & 6,1312 \\
\hline 2 & $-8,2318$ & $48,744^{*}$ & $1,3172^{*}$ & $5,9513^{*}$ & $6,0811^{*}$ & $6,0033^{*}$ \\
\hline \multicolumn{7}{|c|}{ Economic growth and PAD } \\
\hline 0 & $-9,0431$ & NA & 2,2209 & 6,4736 & 6.4996 & 6,4840 \\
\hline 1 & $-8,4318$ & 1,2094 & 1,4767 & 6,0656 & 6.1434 & 6,0968 \\
\hline 2 & $-8,2724$ & $31.306^{*}$ & $1.3560^{*}$ & $5,9803^{*}$ & $6,1101^{*}$ & $6,0324^{*}$ \\
\hline
\end{tabular}

Source: $L H P-\angle K P D$, be treated (BPK 2005-2015) 
According to Table 3, it can be seen that the optimal lag choice is at the 2-year time horizon produced by LR test statistics, Final Predictor Error (FPE), Akaike Information Criteria (AIC), Schwarz Information Criteria (SIC) and Hannan-Quinn Information Criteria ( HQ). The optimal lag selection will use the optimal lag at the 2-year time horizon because it takes into account a closer time period so that it is possible to give an influence between the more optimal variables.

\section{PVECM Analysis}

The PVECM estimation can explain the long run and short run affects between variables. If previously the proposed equation model is PVAR with formulations as in equations (2) and (3), with the change in the estimation model from PVAR to PVECM, then the equation in the model can be written in the following formulation:

$$
\begin{aligned}
& \Delta Y_{i t}=\alpha_{1, i}+\varphi_{1, i} E C T_{i, t-1}+\Sigma_{j=1} \Upsilon_{1, j, i} \Delta Y_{i, t-j}+\Sigma_{j=1} \theta_{1, j, i} \Delta X_{i, t-j}+\mu_{1, i t} \\
& \Delta X_{i t}=\alpha_{2, i}+\varphi_{2, i} E C T_{i, t-1}+\Sigma_{j=2} \Upsilon_{2, j, i} \Delta Y_{i, t-j}+\Sigma_{j=2} \theta_{2, j, i} \Delta X_{i, t-j}+v_{1, i t}
\end{aligned}
$$

where: $\mathrm{i}$ = regency/city $; \mathrm{j}=$ lag optimal; $\mathrm{ECT}=$ Error Correction Term obtained from the cointegration relationship $\theta_{1}$ and $\theta_{2} ; Y=$ endogenous variable $1 ; \quad X=$ endogenous variable 2 .

Economic growth and tax revenue. The estimation results shown in Table 4.4 show that in the long run the tax revenue can affect economic growth significantly at the $95 \%$ confidence level with a coefficient of 0,3459. That means, if tax revenue rises $1 \%$ of GRDP, it will increase economic growth by $0,3459 \%$. On the other hand, also occurs in the long run that economic growth has a significant affect on the $99 \%$ confidence level with a coefficient of 2,8908 . That means, if economic growth rises by $1 \%$, it will increase tax revenues by $2,8908 \%$ of GRDP.

In short run relationships, tax revenue in the first lag significantly affect economic growth at a $99 \%$ confidence level with a coefficient of 0,3639. That means, if the tax revenue for the past period increased by $1 \%$ of GRDP, it would increase economic growth by 0,3639\% at current period. Similarly, in the second lag, the coefficient of tax revenue is 0,4549 , which means that if the tax revenue of the past two periods increased by $1 \%$ of GRDP, it would increase economic growth by $0,4549 \%$. Short run relationship tax revenue variable is also significantly affected by itself with a coefficient of 0,7428 in the first lag and 0,7464 in the second lag. That is, tax revenues affect economic growth on the other hand also affect themselves. 
Table 4. Estimation of economic growth and tax revenue

\begin{tabular}{|c|c|c|c|c|}
\hline \multicolumn{2}{|c|}{ Long run variables } & \multicolumn{3}{|c|}{$\begin{array}{l}\text { Short run variables } \\
\text { D(DIFF_GROWTH) }\end{array}$} \\
\hline DIFF_GROWTH(-1) & 1,0000 & CointEq1 & $-0,7198^{* * *}$ & $-0,0168$ \\
\hline \multirow[t]{2}{*}{ DIFF_TAX_INC(-1) } & $0,3459^{* *}$ & & {$[-12,9572]$} & {$[-0,69947]$} \\
\hline & $\begin{array}{c}{[} \\
2,07591]\end{array}$ & D(DIFF_GROWTH(-1)) & $0,4523^{* * *}$ & 0,0517 \\
\hline C & $-0,0992$ & & {$[3,77814]$} & {$[0,99655]$} \\
\hline & & D(DIFF_GROWTH(-2)) & $0,1411^{\star \star}$ & 0,0241 \\
\hline DIFF_TAX_INC(-1) & 1,0000 & & {$[2,23743]$} & {$[0,88039]$} \\
\hline \multirow[t]{2}{*}{ DIFF_GROWTH(-1) } & $2,8908^{* * *}$ & $\mathrm{D}(\mathrm{DIFF}$ _TAX_INC(-1)) & $0,3639 * * *$ & $-0,7428 * * *$ \\
\hline & {$[12,7049]$} & & {$[2,44894]$} & {$[-11,5308]$} \\
\hline \multirow[t]{4}{*}{ C } & $-0,2868$ & $\mathrm{D}(\mathrm{DIFF}$ _TAX_INC(-2)) & $0,4549^{* * *}$ & $-0,7464^{\star * *}$ \\
\hline & & & {$[2,50065]$} & {$[-9,46340]$} \\
\hline & & C & 0,0664 & $0,0840^{* * *}$ \\
\hline & & & {$[1,22723]$} & {$[3,58165]$} \\
\hline \multicolumn{3}{|c|}{ R-squared } & 0,7613 & 0,4206 \\
\hline \multicolumn{3}{|c|}{ Adj. R-squared } & 0,7563 & 0,4085 \\
\hline \multicolumn{3}{|c|}{ Sum sq. resids } & 150,8826 & 28,3596 \\
\hline \multicolumn{3}{|c|}{ S.E. equation } & 0,7945 & 0,3445 \\
\hline \multicolumn{3}{|c|}{ F-statistic } & 152,4693 & 34,7057 \\
\hline
\end{tabular}

Explanation: Number in [ ] is a t-statistic; ${ }^{* * *}$ significant at level 1\%; ** significant at level 5\%; * significant at level $10 \%$.

Source: LHP-LKPD, be treated (BPK 2005-2015)

On the opposite relationship, namely economic growth with tax revenues found in the short run, but not significant for tax revenues. Economic growth in the short run is significant with a $99 \%$ confidence level in the first lag with a coefficient of 0,4523 and significant with a level of trust in the second lag with a coefficient of 0,1411 .

The value of speed of adjustment coefficient of economic growth equation is $-0,7198$. That means, the adjustment of economic growth to return to equilibrium is quite fast. Coefficient $-0,7198$ shows that the equilibrium adjustment of economic growth in the past period will be corrected by $71,98 \%$ in the current period. On the other hand, the value of coefficient of tax revenue is not significant, meaning that in the previous period there was no adjustment in tax revenue to return to equilibrium at current period.

Based on the estimation results in Table 4, the short run equation model of economic growth and tax revenues are:

$\Delta$ diff_tax_inc $f_{i t}=-0,0168\left(\right.$ diff_tax_inc $_{i t-1}+2,8908$ diff_growth $_{i t-1}-$ 0,2868) - 0,7428 $\Delta$ diff_tax_inc $i t-1-0,7464 \Delta$ diff_tax_inc $_{i t-2}+$ $0,0517 \Delta$ diff_growth ${ }_{i t-1}+0,0240 \Delta$ diff_growth $_{i t-2}+0,0840$

$\Delta$ diff growth $_{i t}=-0,7198$ (diff_tax_inc $_{i t-1}+2,8908$ diff_growth $_{i t-1}-$ $0,2868)+0,3639 \Delta$ diff_tax_inc $i t-1+0,4549 \Delta$ diff_tax_inc $_{i t-2}+$ $0,4523 \Delta$ diff_growth ${ }_{i t-1}+0,1411 \Delta$ diff_growth ${ }_{i t-2}+0,664$ 
Economic growth and retribution revenue. The estimation results in Table 5 between the variables of economic growth and retribution revenue in the long run are retribution revenue can affect economic growth significantly at the $99 \%$ confidence level with a coefficient of 0,5918. That means, if the retribution revenue increases $1 \%$ of the GRDP, it will increase economic growth by $0,5918 \%$. On the other hand, economic growth in the long run is also able to significantly affect retribution revenues at a $99 \%$ confidence level with a coefficient of 1,6897 . That means, if economic growth rises $1 \%$, it will increase retribution revenue by $1,6897 \%$ of GRDP.

Estimated short run relationship, retribution revenue affects economic growth significantly at the $99 \%$ confidence level with a coefficient of 0,7757 in the first lag. That means, retribution revenue in one previous period rose $1 \%$ of GRDP, will affect economic growth by $0,77 \%$ at current period. Similarly, in the second lag, retribution revenue affects economic growth significantly at the $99 \%$ confidence level with a coefficient of 0,4321 . That means, if the retribution revenue for the past two periods rose by $1 \%$ from the GRDP, it would increase economic growth at this time by $0,4321 \%$. In addition, retribution revenue also has a significant affect on the $99 \%$ confidence level in the first lag and the second lag for itself with a coefficient value of $-1,0405$ in the first lag and $-0,4914$ in the second lag. That means, an increase in retribution revenue in one and two previous periods amounting to $1 \%$ of GRDP, will affect the decrease in retribution revenue by $1,0405 \%$ in the first lag and $0,4914 \%$ in the second lag.

The estimation results of economic growth on retribution revenue in the short run is that economic growth affects retribution revenue significantly at the $99 \%$ confidence level with a coefficient of 0,5200 in the first lag. That means, if economic growth in the previous period rose $1 \%$, it would increase retribution revenue by $0,5200 \%$ of the current GRDP. In the second lag, economic growth also still affects retribution revenue significantly at the $99 \%$ confidence level with a coefficient of 0,2708 . That means, if the economic growth of the previous two periods rose by $1 \%$, it would increase the current retribution revenue by $0,2708 \%$ from GRDP.

In estimating economic growth towards itself in the short run, it was found that the first lag economic growth was able to affect itself at $90 \%$ confidence level with a coefficient of 0,1976. However, in the second lag economic growth has no significant affect on itself.

Value of speed of adjustment coefficient of economic growth equation is $-1,0297$. That means, adjusting economic growth to return to equilibrium very quickly. Coefficiency $-1,0297$ shows that the equilibrium adjustment of economic growth in the past period will be corrected by $102 \%$ in the current period. Meanwhile, the value of speed of adjustment coefficient of retribution revenue is $-0,3806$. This shows that the adjustment of retribution revenue to return to 
equilibrium is quite fast because the previous period's equilibrium will be corrected by $38,06 \%$ in the current period.

Table 5. Estimation of economic growth and retribution revenue

\begin{tabular}{|c|c|c|c|c|}
\hline \multicolumn{2}{|c|}{ Long run variables } & \multicolumn{2}{|c|}{$\begin{array}{l}\text { Short run variables } \\
\text { D(DIFF_GROWTH) }\end{array}$} & $\mathrm{D}(\mathrm{DIFF}$ _RET_INC) \\
\hline DIFF_GROWTH(-1) & 1,0000 & CointEq1 & $-1,0297^{\star \star *}$ & $-0.3806^{\star \star \star}$ \\
\hline DIFF_RET_INC(-1) & $0,5918^{* * *}$ & & {$[-11.3095]$} & {$[-4.2255]$} \\
\hline \multirow{3}{*}{ - } & {$[5,1678]$} & D(DIFF_GROWTH(-1)) & $0,1976^{*}$ & $0,5201^{\star * *}$ \\
\hline & $-0,0471$ & & {$[1,71071]$} & {$[4,5500]$} \\
\hline & & D(DIFF_GROWTH(-2)) & 0,0190 & $0,2708^{* * *}$ \\
\hline DIFF_RET_INC(-1) & 1,0000 & & {$[0,30462]$} & {$[4,3783]$} \\
\hline DIFF_GROWTH(-1) & $1,6897^{\star * *}$ & D(DIFF_RET_INC (-1)) & $0,7757^{* * *}$ & $-1,0406^{\star \star *}$ \\
\hline \multirow{5}{*}{ C } & {$[11,6553]$} & & {$[7,43711]$} & {$[-10,0827]$} \\
\hline & 0,0796 & D(DIFF_RET_INC (-2)) & $0,4321^{\star \star \star}$ & $-0.491423^{\star \star \star}$ \\
\hline & & & {$[3,97232]$} & {$[-4,5656]$} \\
\hline & & C & 0,0447 & 0,0274 \\
\hline & & & {$[0,80281]$} & {$[0,4969]$} \\
\hline \multicolumn{3}{|c|}{ R-squared } & 0,7315 & 0,5900 \\
\hline \multicolumn{3}{|c|}{ Adj. R-squared } & 0,7259 & 0,5814 \\
\hline \multirow{3}{*}{\multicolumn{3}{|c|}{$\begin{array}{l}\text { Sum sq. resids } \\
\text { S.E. equation } \\
\text { F-statistic }\end{array}$}} & 169,7366 & 166,1769 \\
\hline & & & 0,8427 & 0,8338 \\
\hline & & & 130,2238 & 68,7839 \\
\hline
\end{tabular}

Explanation: Number in [] is a t-statistic; ${ }^{* *}$ significant at level 1\%; ${ }^{* *}$ significant at level 5\%; * significant at level $10 \%$.

Source: $L H P-L K P D$, be treated (BPK 2005-2015)

Based on the estimation results in Table 5, the short run equation model of economic growth and retribution revenue are:

$\Delta$ diff ret $_{\text {inc }}$ it $=$ $-0,3806$ (diff_ret_inc $i t-1+1,6897$ diff_growth $\left.{ }_{i t-1}-0,0796\right)-$ 1,0405 $\Delta$ diff_ret_inc ${ }_{i t-1}-0,4914$ diff_ret_inc $i t-2+$ $0,5200 \Delta$ diff_growth ${ }_{i t-1}+0,2708 \Delta$ diff_growth ${ }_{i t-2}+0,0273$

$\Delta$ diff growth $_{i t}=$ $-1,0297$ (diff_ret_inc $i t-1+1,6897$ diff_growth $\left._{i t-1}-0,0796\right)+$ $0,7757 \Delta$ diff_ret_inc $i t-1+0,4321 \Delta$ diff_ret_inc $i t-2+$ $0,1976 \Delta$ diff_growth ${ }_{i t-1}+0,0190 \Delta$ diff_growth it $-2_{2}+0,0466$

Economic growth and regional wealth revenue. The estimation result in Table 6 between economic growth and regional wealth revenue is the economic growth has a significant affect on regional wealth revenue at $99 \%$ confidence level with a coefficient of $-1,7921$. That means, in the long run, the economic growth of $1 \%$, will reduce regional wealth revenue by $1,7921 \%$ of GDRP. In contrary, regional wealth revenue do not significantly affects economic growth in the long run. 
In the short run, economic growth has a significant affect on regional wealth revenue in the first lag. At a $90 \%$ confidence level, the value of coefficient of economic growth is $-0,0679$. That means, if the economic growth rose by $1 \%$, will decrease regional wealth revenue by $0,06 \%$ of GDRP. Meanwhile, in the second lag, economic growth has no significant affect on regional wealth revenue. In addition to affecting regional wealth revenue, economic growth also affects itself in the first lag at 99\% confidence level with 0,4504 and in the second lag at 95\% confidence level with coefficient of 0,1361.

The estimation of the affect of regional wealth revenue on economic growth is found that regional wealth revenue has a significant affect on economic growth at a 99\% confidence level with a coefficient of $-1,1328$ in the first lag. In the second lag, regional wealth revenue has a significant affect on economic growth at a 95\% confidence level with a coefficient of $-1,2207$. That means, if the regional wealth revenue in the previous period rose by $1 \%$, will reduce economic growth by $1,1328 \%$ and in the previous two periods reduce economic growth by $1,2207 \%$ at current period. The affect of regional revenue wealth on itself is significant at the $99 \%$ confidence level in the first lag and the second lag. The coefficient on the first lag is $-1,7676$ and in the second lag is 1,0770 . This means that current regional wealth revenues will decrease by $1,7676 \%$ of GRDP if regional wealth revenue in the previous period rises by $1 \%$ from GRDP. Likewise, if in the previous two periods regional revenue has increased by $1 \%$ of GDRP, it would have caused a decrease in revenue of regional wealth by $-1,0770 \%$ of current GRDP.

The coefficient of speed of adjustment of economic growth is 1,1624. That means, economic growth to return to equilibrium is very quickly. 1,1624 coefficient which shows the economic equilibrium growth for the period to be corrected by $-116 \%$ in the current period. Meanwhile, the coefficient of speed of adjustment of regional wealth revenue is $-0,0479$. This shows that the adjustment of regional wealth revenue to return to equilibrium is quite slow because the previous period's equilibrium will be corrected by $4,79 \%$ in the current period so that it takes 20 periods to reach equilibrium.

Based on the results in Table 6, the short run equation model of economic growth and regional revenue are:

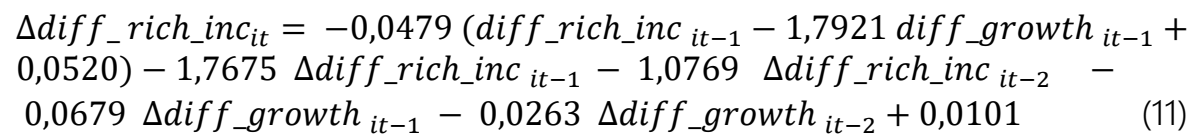


$\Delta$ diff growth $_{i t}=$

1,1624 (diff_rich_inc ${ }_{i t-1}-1,7921$ diff_growth $\left._{i t-1}+0,0520\right)-$

$1,1328 \Delta d i f f_{-}$rich_inc $i t-1-1,2207 \Delta$ diff_rich_inc ${ }_{i t-2}+$

$0,4504 \Delta$ diff_growth ${ }_{i t-1}+0,1361 \Delta$ diff_growth ${ }_{i t-2}+0,1312$

Table 6. Estimation of economic growth and regional wealth revenue

\begin{tabular}{|c|c|c|c|c|}
\hline \multicolumn{2}{|c|}{ Long run variables } & \multicolumn{2}{|c|}{$\begin{array}{c}\text { Short run variables } \\
\text { D(DIFF_GROWTH) }\end{array}$} & \multirow{2}{*}{$\frac{\mathrm{D}\left(\mathrm{DIFF} \mathrm{RICH}_{-} \mathrm{INC}\right)}{0,0479^{\star}}$} \\
\hline DIFF_GROWTH(-1) & 1,0000 & CointEq1 & $1,1624^{\star \star \star}$ & \\
\hline DIFF_RICH_INC(-1) & $\begin{array}{c}-0,5580 \\
{[-0,95160]}\end{array}$ & D(DIFF_GROWTH(-1)) & $\begin{array}{l}{[-12,7083]} \\
0,4504^{\star \star \star}\end{array}$ & $\begin{array}{l}{[1,83913]} \\
-0,0680^{*}\end{array}$ \\
\hline C & $-0,0291$ & D(DIFF_GROWTH(-2)) & $\begin{array}{c}{[3,67448]} \\
0,1361^{\star *}\end{array}$ & $\begin{array}{c}{[-1,94695]} \\
-0,0263\end{array}$ \\
\hline $\begin{array}{l}\text { DIFF_RICH_INC(-1) } \\
\text { DIFF_GROWTH(-1) }\end{array}$ & $\begin{array}{r}1,0000 \\
-1,7921^{* * *}\end{array}$ & D(DIFF_RICH_INC(-1)) & $\begin{array}{c}{[2,1142]} \\
-1,1328^{\star \star \star}\end{array}$ & $\begin{array}{l}{[-1,43315]} \\
-1,7676^{\star \star \star}\end{array}$ \\
\hline c & $\begin{array}{c}{[-12,6945]} \\
0,0521\end{array}$ & $\begin{array}{c}\mathrm{D}\left(\mathrm{DIFF} \mathrm{RICH}_{-} \mathrm{INC}(-2)\right) \\
\mathrm{C}\end{array}$ & $\begin{array}{c}{[-4,32685]} \\
-1,2208^{\star \star} \\
{[-2,19710]} \\
0,1313^{\star \star \star} \\
{[2,38379]}\end{array}$ & $\begin{array}{c}{[-23,7093]} \\
-1,0770 * * \\
{[-6,80704]} \\
0,0102 \\
{[0,64918]}\end{array}$ \\
\hline \multicolumn{3}{|c|}{ R-squared } & 0,7544 & 0.735687 \\
\hline \multicolumn{3}{|c|}{ Adj. R-squared } & 0,7493 & 0.730157 \\
\hline \multirow{2}{*}{\multicolumn{3}{|c|}{$\begin{array}{l}\text { Sum sq. resids } \\
\text { S.E. equation }\end{array}$}} & 155,2317 & 12,5872 \\
\hline \multirow{2}{*}{\multicolumn{3}{|c|}{$\begin{array}{l}\text { S.E. equation } \\
\text { F-statistic }\end{array}$}} & 0,8059 & 0,2295 \\
\hline & & & 146,8583 & 133,0462 \\
\hline
\end{tabular}

Explanation: Number in [ ] is a t-statistic; ${ }^{* * *}$ significant at level 1\%; ** significant at level 5\%; * significant at level $10 \%$.

Source: $L H P-L K P D$, be treated (BPK 2005-2015)

Economic growth and other legitimate revenue. The estimation results in Table 7 show that economic growth with other legitimate revenue in the long run, economic growth has a significant affect on other legitimate revenue at $99 \%$ confidence level with a coefficient of $-527,7366$. In contrary, other legitimate revenue does not have a significant affect on long run economic growth.

The estimation result in the short run, found that each variable only affects itself in the first lag and the second lag. The economic variable does not have a significant affect on other legitimate revenue, likewise other legitimate revenue variables also has not a significant affect on economic growth in the short run. Economic growth has a significant affect on itself in the first lag with a coefficient of 0,4698 at a confidence level of $99 \%$ and in the second lag with a coefficient of 0,1432 at a confidence level of $95 \%$. That means, economic growth of $1 \%$ in one and two previous periods increased economic growth of $0,4698 \%$ and $0,1432 \%$ at current period.

Other legitimate revenue also has a significant affect on itself with a $99 \%$ confidence level in the first lag and the second lag with coefficients of - 
1,4066 and $-1,5309$. That means, an increase in the other legitimate revenue of $1 \%$ of the GRDP in the previous period will reduce the current $1,4066 \%$ legitimate revenue from GRDP. Increasing 1\% in the other legitimate revenue of GRDB in the previous two periods will reduce 1,5309\% of the other legitimate revenue from GRDP at current period.

Table 7. Estimation of economic growth other legitimate revenue

\begin{tabular}{|c|c|c|c|c|}
\hline Long run vari & ables & \multicolumn{2}{|c|}{$\begin{array}{c}\text { Short run variables } \\
\text { D(DIFF_GROWT } \\
H)\end{array}$} & $\begin{array}{c}\text { D(DIFF_OTHER_IN } \\
C)\end{array}$ \\
\hline DIFF_GROWTH(-1) & 1,0000 & CointEq1 & $0,0039 * \star \star$ & $-0,0007$ \\
\hline DIFF_OTHER_INC(-1) & $-0,0019$ & & {$[-12,6774]$} & {$[1,2124]$} \\
\hline \multirow{4}{*}{ 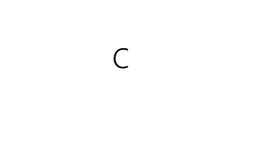 } & {$[-0,0321]$} & D(DIFF_GROWTH(-1)) & $0,4698^{\star \star \star}$ & $-0,2915$ \\
\hline & $-0,0459$ & & {$[3,7817]$} & {$[-1,1704]$} \\
\hline & & D(DIFF_GROWTH(-2)) & $0,1432^{\star *}$ & $-0,1626$ \\
\hline & & & {$[2,2047]$} & {$[-1,24847]$} \\
\hline DIFF_OTHER_INC(-1) & 1,0000 & D(DIFF_OTHER_INC(-1)) & $-0,0162$ & $-1,4066^{\star \star \star}$ \\
\hline \multirow[t]{2}{*}{ DIFF_GROWTH(-1) } & $-527,7366^{* * *}$ & & {$[-0,5198]$} & {$[-22,5664]$} \\
\hline & {$[-12,7710]$} & D(DIFF_OTHER_INC(-2)) & $-0,0251$ & $-1,5310^{* * *}$ \\
\hline \multirow[t]{2}{*}{ C } & 24,2319 & & {$[-0,4190]$} & {$[-12,7702]$} \\
\hline & & C & $\begin{array}{l}0,1099 * * \\
{[2,0120]}\end{array}$ & $\begin{array}{c}0,2819 * * * \\
{[2,5741]}\end{array}$ \\
\hline \multicolumn{3}{|c|}{ R-squared } & 0,7541 & 0,6964 \\
\hline \multicolumn{3}{|c|}{ Adj. R-squared } & 0,7489 & 0,6901 \\
\hline \multicolumn{3}{|c|}{ Sum sq. resids } & 155,4656 & 624,8687 \\
\hline \multicolumn{3}{|c|}{ S.E. equation } & 0,8065 & 1,6169 \\
\hline \multicolumn{3}{|c|}{ F-statistic } & 146,5655 & 109,6641 \\
\hline
\end{tabular}

Explanation: Number in [ ] is a t-statistic; *** significant at level 1\%; ** significant at level 5\%; * significant at level $10 \%$.

Source: $L H P-L K P D$, be treated (BPK 2005-2015)

The value of speed of adjustment coefficient of economic growth equation is 0,0039 . This means that the adjustment of economic growth to return to equilibrium is very slow. The coefficient of 0,0039 indicates that the equilibrium adjustment of economic growth in the previous period will be corrected by $-0,39 \%$ in the current period. Meanwhile, the coefficient of speed of adjustment of other legitimate revenue is not significant.

Based on the estimation results in Table 7, the short run equation model of economic growth and other legitimate revenue are:

$\Delta$ diff $f_{-}$other_inc $i t=-0,0007$ (diff_other_inc ${ }_{i t-1}-$ 527,7365 diff_growth it $\left.-1_{1}+24,2319\right)-1,4066$ diff_other_inc ${ }_{i t-1}-$ 1,5309 $\Delta$ diff_other_inc ${ }_{i t-2}-0,2915 \Delta$ diff_growth_inc $_{i t-1}-$ $0,1626 \Delta$ diff_growth ${ }_{i t-2}+0,2819$

$\Delta$ diff_ growth $_{i t}=0,0039$ (diff_other_inc $_{\text {it }-1}-$

527,7365 diff_growth $\left.{ }_{i t-1}+24,2319\right)-0,0161 \Delta$ diff_other_inc $_{i t-1}-$ $0,0250 \Delta$ diff_other_inc ${ }_{i t-2}+0,4698 \Delta$ diff_growth_inc $_{i t-1}+$

0,1432 $\Delta$ diff_growth ${ }_{i t-2}+0,1099$ 
Economic growth and PAD. The estimation results in Table 8 between economic growth and PAD can be found in the long run PAD does not have a significant effect on economic growth. On the other hand, economic growth in the long run has a significant affect on PAD at a $99 \%$ confidence level with a coefficient of 15,4051 . That is, a $1 \%$ increase in economic growth in the long run will affect the increase in PAD of $15,4051 \%$ of GRDP.

Economic growth in the first lag and the second lag significantly affects itself at a 99\% confidence level in the first lag and 95\% in the second lag. In the first lag the coefficient of economic growth is 0,4575 and the second lag is 0,1349 . That means, the economic growth in the first lag contributed to the current economic growth of 0,4574\% and the second lag contributed 0,1349\%. The coefficient of economic growth is 0.4575 and the second lag is 0,1349 . That is, the economic growth in the first lag contributed to the current economic growth of $0,4574 \%$ and the second lag contributed $0,1349 \%$. Similarly, significant PAD affects itself at the $99 \%$ confidence level with a coefficient of 1,4619 in the first lag and $-1,6000$ in the second lag. That is, the PAD in the first lag contributes $-1,4619 \%$ of the current GRDP to the PAD. The second lag contributes to $-1,6000 \%$ of current GRDP to PAD.

Table 8. Estimation of economic growth and PAD

\begin{tabular}{|c|c|c|c|c|}
\hline \multicolumn{2}{|c|}{ Long run variables } & \multicolumn{3}{|c|}{ Short run variables } \\
\hline \multirow{4}{*}{$\begin{array}{c}\text { DIFF_PAD(-1) } \\
\text { DIFF_GROWTH(-1) }\end{array}$} & & & & \\
\hline & 1,0000 & CointEq1 & 0,0155 & $-0,1364^{\star \star \star}$ \\
\hline & $15,4051^{\star * *}$ & & {$[0,7246]$} & {$[-12,7951]$} \\
\hline & {$[12,7163]$} & D(DIFF_PAD(-1)) & $-1,4620^{\star \star \star}$ & $0,0842^{\star \star}$ \\
\hline \multirow[t]{2}{*}{ C } & $-1,2916$ & & {$[-20,1134]$} & {$[2,3217]$} \\
\hline & & D(DIFF_PAD(-2)) & $-1,6000^{\star \star \star}$ & 0,0471 \\
\hline DIFF_GROWTH(-1) & 1,0000 & & {$[-11,1729]$} & {$[0,6586]$} \\
\hline \multirow[t]{2}{*}{ DIFF_PAD(-1) } & 0,0649 & D(DIFF_GROWTH(-1)) & $-0,1422$ & $0,4575^{\star * *}$ \\
\hline & {$[1,0128]$} & & {$[-0,5807]$} & {$[3,7453]$} \\
\hline \multirow[t]{7}{*}{ C } & $-0,0838$ & D(DIFF_GROWTH(-2)) & $-0,0121$ & $0,1349 * *$ \\
\hline & & C & $\begin{array}{c}{[-0,0941]} \\
0,4426^{\star \star \star} \\
{[4,0165]}\end{array}$ & $\begin{array}{c}{[2,1089]} \\
0,0834 \\
{[1,5164]}\end{array}$ \\
\hline & & R-squared & 0,6814 & 0,7571 \\
\hline & & Adj. R-squared & 0,6747 & 0,7520 \\
\hline & & Sum sq. resids & 616,9944 & 153,5596 \\
\hline & & S.E. equation & 1,6067 & 0,8016 \\
\hline & & F-statistic & 102,2089 & 148,9779 \\
\hline
\end{tabular}

Explanation: Number in [ ] is a t-statistic; ${ }^{* \star *}$ significant at level 1\%; ${ }^{* *}$ significant at level $5 \%$; * significant at level $10 \%$.

Source: LHP-LKPD, be treated (BPK 2005-2015)

The value of speed of adjustment coefficient of economic growth equation is $-0,1364$. This means that the adjustment of economic growth to return to equilibrium is quite slow. The coefficient of $-0,1364$ shows that the economic growth equilibrium adjustment in the previous period was corrected 
by $13,64 \%$ in the current period. Meanwhile, the value of the speed of adjustment PAD coefficient is not significant.

Based on the estimation results in Table 8, the short run equation model of economic growth and PAD are:

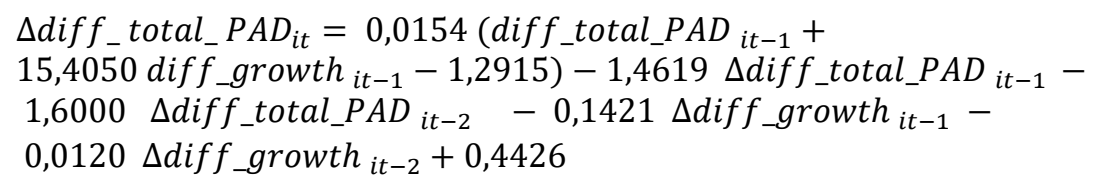

$\Delta$ diff growth $_{i t}=-0,1364\left(\right.$ diff_total_PAD $_{i t-1}+$ $15,4050$ diff_growth $i t-1-1,2915)+0,0841 \Delta$ diff_total_PAD ${ }_{i t-1}+$ $0,0470 \Delta$ diff_total_PAD ${ }_{i t-2}+0,4575 \Delta$ diff_growth $_{i t-1}+$ $0,1349 \Delta$ diff_growth ${ }_{i t-2}+0,0833$

\section{Granger Causality Test with PVECM}

Granger Causality Test is conducted to determine the direction of causality between economic growth with tax revenue, economic growth with retribution revenue, economic growth with regional wealth revenue, economic growth with other legitimate revenue, and economic growth with PAD.

Based on the test results in Table 9, it is known that there is a one-way relationship namely tax revenue to economic growth. This is consistent with the PVECM estimates in Table 4. The probability value is $0,0077<0,05$ in the first lag and 0,0171<0,05 in the second lag, which means that tax revenue has a significant affect on economic growth in the short run.

In the second Granger test between economic growth and retribution revenue, it was found that there was a reciprocal or two-way relationship. Economic growth affects retribution revenue and retribution revenue affects economic growth. This is consistent with the results of the PVECM estimation in Table 5. The probability value is $0,00<0,05$ in the first lag and 0,00<0,05 in the second lag, which means that revenue retribution and economic growth have significant affect in the short run.

The third Granger test between economic growth and regional wealth revenue, there is a one-way relationship namely regional wealth revenue to economic growth. This is consistent with the PVECM estimates in Table 6 before. Probability value 0,0049<0,05 in the first lag and 0,0001<0,05 in the second lag, which means that regional wealth revenue has a significant affect on economic growth in the short run. 
Table 9. PVECM Granger Causality Test results

\begin{tabular}{|c|c|c|c|c|}
\hline \multirow{2}{*}{$\begin{array}{c}\text { Endogenous } \\
\text { variables }\end{array}$} & \multicolumn{4}{|c|}{ Exogenous variables } \\
\hline & $\Delta$ growth $_{\mathrm{t}-2}$ & $\Delta$ tax_inc $t-2$ & $\Delta$ growth $_{\mathrm{t}-1}$ & $\Delta$ tax_inc $_{\mathrm{t}-1}$ \\
\hline$\Delta$ growth & -- & $\begin{array}{c}8,1333 \\
(0,0171)\end{array}$ & -- & $\begin{array}{c}7,0907 \\
(0,0077)\end{array}$ \\
\hline$\Delta$ tax_inc & $\begin{array}{c}0,9997 \\
(0,6066) \\
\end{array}$ & -- & $\begin{array}{c}0,3417 \\
(0,5588) \\
\end{array}$ & -- \\
\hline \multirow{2}{*}{$\begin{array}{c}\text { Endogenous } \\
\text { variables }\end{array}$} & \multicolumn{4}{|c|}{ Exogenous variables } \\
\hline & $\Delta$ growth $_{\mathrm{t}-2}$ & $\Delta$ ret_inc $\mathrm{t}_{\mathrm{t}-2}$ & $\Delta$ growth $_{\mathrm{t}-1}$ & $\Delta$ ret_inc $_{\mathrm{t}-1}$ \\
\hline$\Delta$ growth & -- & $\begin{array}{c}5,5568 \\
(0,0000)\end{array}$ & -- & $\begin{array}{l}19,7345 \\
(0,0000)\end{array}$ \\
\hline$\Delta$ ret_inc & $\begin{array}{c}2,2075 \\
(0,0000)\end{array}$ & -- & $\begin{array}{c}1,1267 \\
(0,0000)\end{array}$ & -- \\
\hline
\end{tabular}

\begin{tabular}{l|cccc}
\hline \multirow{2}{*}{$\begin{array}{c}\text { Endogenous } \\
\text { variables }\end{array}$} & \multicolumn{4}{|c}{ Exogenous variables } \\
\cline { 2 - 5 } & $\Delta$ growth t-2 & $\Delta$ rich_inc t-2 & $\Delta$ growth t-1 & $\Delta$ rich_inc t-1 \\
\hline$\Delta$ growth & -- & 1,9357 & -- & 7,9275 \\
& & $(0,0001)$ & & $(0,0049)$ \\
$\Delta$ rich_inc & 3,9384 & -- & 0,7889 & -- \\
& $(0,1396)$ & & $(0,3744)$ & \\
\hline
\end{tabular}

\begin{tabular}{l|cccc}
\hline \multirow{2}{*}{$\begin{array}{c}\text { Endogenous } \\
\text { variables }\end{array}$} & \multicolumn{4}{|c}{ Exogenous variables } \\
\cline { 2 - 5 } & $\Delta$ growth t-2 & $\Delta$ other_inc t- & $\Delta$ growth t-1 & $\Delta$ other_inc t- \\
\hline vgrowth & -- & 2 & -- & 1,9275 \\
& & 1,6063 & & $(0,6939)$ \\
sother_inc & 0,2772 & $-0,8727)$ & 0,7889 & -- \\
& $(0,4479)$ & & $(0,9466)$ & \\
\hline
\end{tabular}

\begin{tabular}{|c|c|c|c|c|}
\hline \multirow{2}{*}{$\begin{array}{c}\text { Endogenous } \\
\text { variables }\end{array}$} & \multicolumn{4}{|c|}{ Exogenous variables } \\
\hline & $\Delta$ growth $_{\mathrm{t}-2}$ & $\Delta$ pad $\mathrm{t}-2^{2}$ & $\Delta$ growth $_{\mathrm{t}-1}$ & $\Delta$ pad $_{\mathrm{t}-1}$ \\
\hline$\Delta$ growth & -- & $\begin{array}{c}8,9042 \\
(0,2964)\end{array}$ & -- & $\begin{array}{c}1,0905 \\
(0,0117)\end{array}$ \\
\hline$\Delta$ pad & $\begin{array}{c}0,8674 \\
(0,6481)\end{array}$ & -- & $\begin{array}{c}0,9116 \\
(0,3397)\end{array}$ & -- \\
\hline
\end{tabular}

Source: $L H P-L K P D$, be treated (BPK 2005-2015)

The fourth Granger test between economic growth and other legitimate revenue does not occur in a mutually influential relationship. This is consistent with the PVECM estimates in Table 7. The probability value of the two variables in the first lag and the second lag is greater than 0.05, meaning that other 
legitimate revenue and economic growth are not mutually influential in the short run.

The fifth Granger test between economic growth and PAD has a oneway relationship, namely PAD to economic growth. This is consistent with PVECM estimates in Table 8 . The probability value is 0,0117<0,05 in the first lag and 0,2964>0,05 in the second lag, which means that PAD has a significant affect on economic growth in the short run, especially in the first lag.

The finding of the relationship between the one-way variable tax revenue towards the variable economic growth has a positive and significant direction in line with the research of Easterly and Rebelo (1993), limi (2005), Arnold (2008), Hammond and Tosun (2009), Myles (2009), Xing (2011), Bacarreza, Vazquez, and Vulovic (2013), Bujang, Hakim, and Ahmad (2013), Stoilova and Patonov (2013), Szarowska (2013), Devkota (2014), Mutiara (2015), Takumah and lyke (2015), Saidin, Basit, and Hamza (2016), as well as Stoilova (2017).

The findings of the reciprocal/two-way relationship between the retribution revenue variable and the variable economic growth are positively and significantly directed in line with Mutiara (2015) research. However, Mutiara (2015) only examines the relationship of retribution revenue to economic growth and not vice versa. The findings of the one-way relationship between the PAD variable and the variable economic growth are positively and significantly directed in line with Putri's research (2015), Hedriwiyanto (2016), Rori, Luntungan, and Niode (2016), Manek and Badrudin (2016), Muti'ah (2017) .

\section{Test the equation models}

The equation models to be tested are equations (8), (9), (10), (12), and (16), which are equations that have significance between independent variables and non-independent variables in the estimation of the PVECM models. Test model equations using stability test, portmanteau normality test, linearity test, heteroscedacity test, and multicollinearity test. The result is that the equation model is free from the assumptions of symptoms of instability with modulus of value below one, free from abnormalities, linear functioning equations, free from heteroscedacity and multicolinearity occurring only in long run economic growth variables.

\section{Summary of findings of PVECM estimation and Granger Causality Test}

After the classic assumption test, it can be said that the equation models obtained from the PVECM estimation is the best equation models. Therefore, the results of the PVECM estimation can be summarized to more easily understand the findings in this study shown in Table 10. 
Table 10. Summary of findings of PVECM estimation and Granger Causality Test

\begin{tabular}{|c|c|c|c|c|c|}
\hline No. & $\begin{array}{c}\text { Equation test } \\
\text { variable }\end{array}$ & $\begin{array}{l}\text { Direction of } \\
\text { relationship }\end{array}$ & $\begin{array}{c}\text { Lag } \\
\text { length }\end{array}$ & Coefficient & Significance \\
\hline \multirow[t]{2}{*}{1.} & \multirow{2}{*}{$\begin{array}{l}\text { Tax revenue } \\
\text { and } \\
\text { economic } \\
\text { growth }\end{array}$} & \multirow{2}{*}{$\begin{array}{l}\text { One-way, } \\
\text { Tax revenue } \\
\text { affects } \\
\text { economic } \\
\text { growth }\end{array}$} & First lag & 0,3639 & $1 \%$ \\
\hline & & & $\begin{array}{l}\text { Second } \\
\text { lag }\end{array}$ & 0,4549 & $1 \%$ \\
\hline \multirow[t]{4}{*}{2.} & \multirow{4}{*}{$\begin{array}{l}\text { Retribution } \\
\text { revenue and } \\
\text { economic } \\
\text { growth }\end{array}$} & $\begin{array}{l}\text { Two-way, } \\
\text { Retribution }\end{array}$ & First lag & 0,7757 & $1 \%$ \\
\hline & & $\begin{array}{l}\text { revenue } \\
\text { affects } \\
\text { economic } \\
\text { growth }\end{array}$ & $\begin{array}{l}\text { Second } \\
\text { lag }\end{array}$ & 0,4321 & $1 \%$ \\
\hline & & $\begin{array}{l}\text { Economic } \\
\text { growth affects }\end{array}$ & First lag & 0,5201 & $1 \%$ \\
\hline & & $\begin{array}{l}\text { retribution } \\
\text { revenue }\end{array}$ & $\begin{array}{l}\text { Second } \\
\text { lag }\end{array}$ & 0,2708 & $1 \%$ \\
\hline \multirow[t]{2}{*}{3.} & \multirow{2}{*}{$\begin{array}{l}\text { Regional } \\
\text { wealth } \\
\text { revenue and } \\
\text { economic } \\
\text { growth }\end{array}$} & \multirow{2}{*}{$\begin{array}{l}\text { One-way, } \\
\text { Regional } \\
\text { wealth } \\
\text { revenue } \\
\text { affects } \\
\text { economic } \\
\text { growth }\end{array}$} & First lag & $-1,1328$ & $1 \%$ \\
\hline & & & $\begin{array}{l}\text { Second } \\
\text { lag }\end{array}$ & $-1,2208$ & $5 \%$ \\
\hline 4. & $\begin{array}{l}\text { Other } \\
\text { legitimate } \\
\text { revenue and } \\
\text { economic } \\
\text { growth }\end{array}$ & $\begin{array}{l}\text { Not affect } \\
\text { each other }\end{array}$ & -- & -- & -- \\
\hline \multirow[t]{2}{*}{5.} & \multirow{2}{*}{$\begin{array}{l}\text { PAD and } \\
\text { economic } \\
\text { growth }\end{array}$} & \multirow{2}{*}{$\begin{array}{l}\text { One-way, PAD } \\
\text { affects } \\
\text { economic } \\
\text { growth }\end{array}$} & First lag & 0,0842 & $5 \%$ \\
\hline & & & $\begin{array}{l}\text { Second } \\
\text { lag }\end{array}$ & 0,0471 & $\begin{array}{c}\text { Not } \\
\text { significant }\end{array}$ \\
\hline
\end{tabular}

Source: $L H P-L K P D$, be treated (BPK 2005-2015) 


\section{Impulse Response Function (IRF)}

According to Enders (2004), the IRF function is obtained through a model in the form of a vector moving average, namely the coefficient of the variable is a response to the existence of innovation. The horizontal axis is the time in the annual period to the future after a disturbance occurs and the vertical axis is the value of the response coefficient. The response that can be seen from the IRF is a positive and negative response. In the short run, the response generated is usually quite significant and volatile.

Figure 4. Impulse Response Function (IRF) economic growth and tax revenue

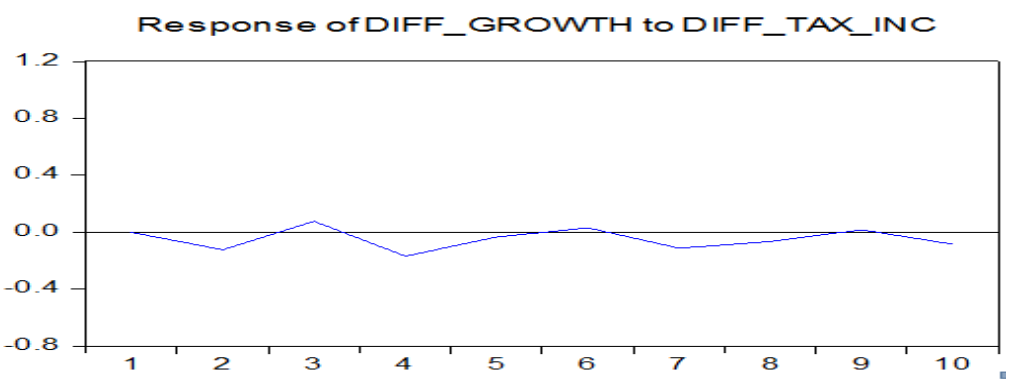

Source: $L H P-L K P D$ BPK 2005-2015, be treated

IRF analysis for economic growth from tax revenues. In Figure 4 shows the shock on tax revenue in the first period has no affect on economic growth. In the second period, the shock that occurred in tax revenue was responded negatively by 0,1224 by economic growth. In the third period the tax revenue shock responded positively at 0,0788 by economic growth. Furthermore, each period of tax revenue shocks affects fluctuations between positive and negative until the tenth period of tax revenue shocks responds to economic growth of 0,0841 .

Figure 5. Impulse Response Function (IRF) Economic Growth and Retribution Revenue
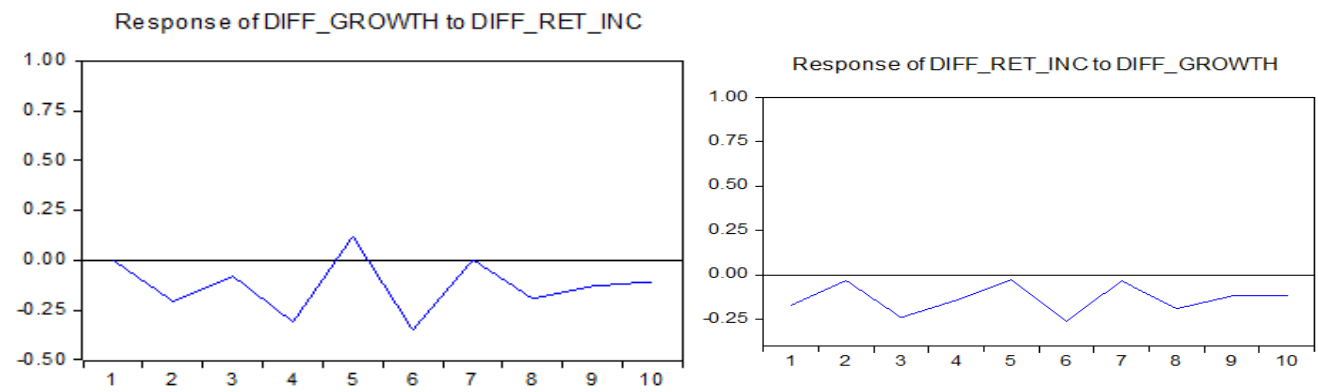

Source: LHP-LKPD BPK 2005-2015, be treated

IRF analysis fo economic growth and retribution revenues. In Figure 5 there are two images that show the response of economic growth from shocks 
that occur in retribution revenue and response to retribution revenue from shocks that occur in economic growth.

Figure 5 on the left shows the response of economic growth to the shock that occurred when retribution revenues did not exist in the first period. The second period, the shock on retribution revenues responded negatively 0,2072 by economic growth and a negative response continued until the fourth period. The tenth period of response that occurred from disruption to retribution revenue was still negative. This indicates that if there is a disruption in the receipt of retribution, it will cause economic growth to decline so that the regional government needs to maintain stability and increase its retribution revenue.

Figure 5 on the right shows almost the same thing, namely the response of retribution revenue to the disruption that occurred in economic growth in the first period until the tenth period is negative. In the first period the response to retribution revenue was $-0,1719$ and continued to fluctuate negatively to the largest in the third and sixth periods which ranged from -0,2403 and -0,2612.

IRF analysis for economic growth from regional wealth revenues. Figure 6 shows the response of economic growth to shocks that occur in regional wealth revenue. It can be seen that the shocks to regional wealth revenue in the first period have not affected economic growth. In the third period, shocks began to be responded to by fluctuating economic growth.

Figure 6. Impulse Response Function (IRF) Economic Growth and Regional Wealth Revenue

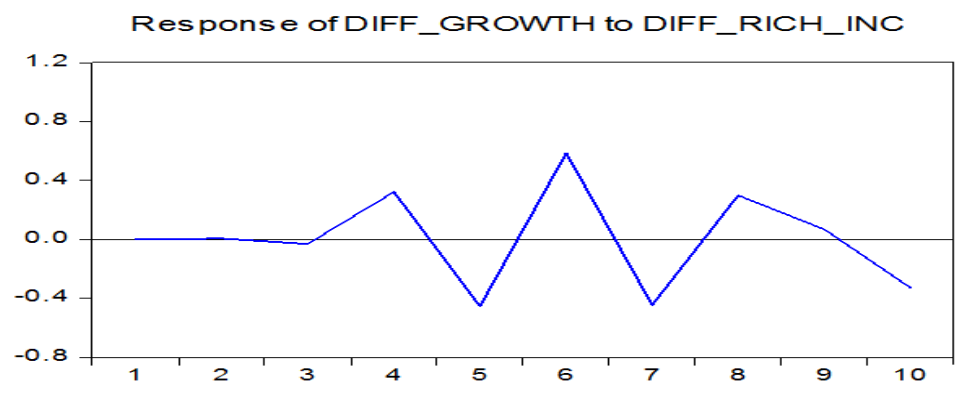

Source: LHP-LKPD BPK 2005-2015, be treated

The fourth period, the response of economic growth is positive 0,3226 and then fluctuates between positive and negative. The tenth period, there is still a negative response of 0,3282 by economic growth on regional wealth revenue. This shows the need to maintain the stability of regional wealth revenues so that economic growth remains stable.

IRF analysis for economic growth and PAD. Figure 7 shows the response of economic growth to shocks that occur in PAD. In the first period, PAD shocks were not responded to by economic growth. From the second period to the 
tenth period, the shock of the PAD was responded to by economic growth as it fluctuated with positive and negative values each period. This indicates that local governments need to maintain stability from PAD so that economic growth remains stable.

Figure 7. Impulse Response Function (IRF) economic growth and PAD

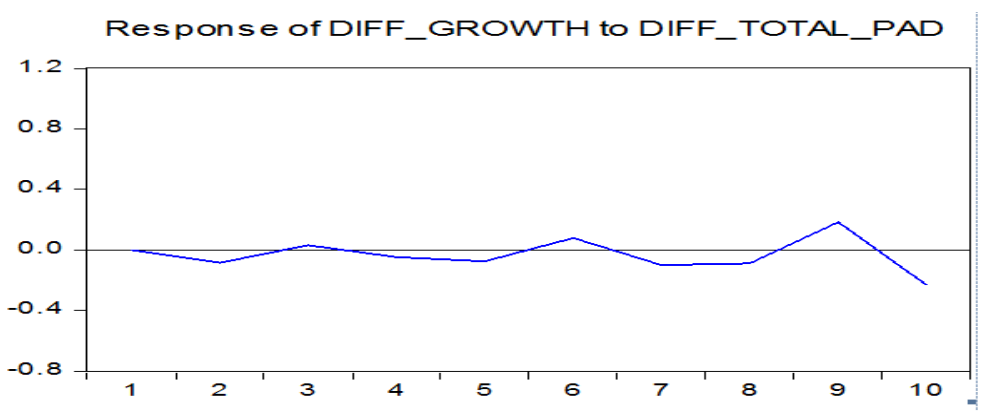

Source: LHP-LKPD BPK 2005-2015, be treated

\section{Variance Decomposition Analysis (VDA)}

Variance decomposition estimates the importance of the role of a variable to other variables in the VAR/VECM system. Enders (2004) states that VDA serves to predict the variance proportion of a variable caused by the existence of a disturbance in the VAR/VECM equation. Predictive variants are generated from the variable itself and other variables on the model.

The VDA analysis in Table 11 shows that the VDA between economic growth and tax revenue shows that the biggest contribution that influences the variable of economic growth and tax revenue comes from the variable itself. Variable tax revenue in the first period of economic growth has not contributed.

Table 11. VDA of economic growth and tax revenue

\begin{tabular}{cccccccc}
\hline \multicolumn{3}{c}{ Variance Decomposition of DIFF_GROWTH: } & \multicolumn{5}{c}{ Variance Decomposition of DIFF_TAX_INC: } \\
\hline Perioc & S.E. & JIFF_GROWTH & DIFF_TAX_INC Period & S.E. & $\begin{array}{c}\text { DIFF_GROWT } \\
\text { H }\end{array}$ & DIFF_TAX_INC \\
\hline 1 & 0,7945 & 100,0000 & 0,0000 & 1 & 0,3445 & 0,3052 & 99,6948 \\
2 & 0,9500 & 98,3394 & 1,6606 & 2 & 0,3543 & 0,3272 & 99,6728 \\
3 & 0,9559 & 97,6793 & 2,3207 & 3 & 0,3555 & 0,7045 & 99,2955 \\
4 & 0,9703 & 94,7891 & 5,2109 & 4 & 0,4431 & 0,4617 & 99,5383 \\
5 & 0,9718 & 94,6935 & 5,3065 & 5 & 0,4608 & 0,5550 & 99,4450 \\
6 & 0,9729 & 94,5950 & 5,4050 & 6 & 0,4632 & 0,6403 & 99,3597 \\
7 & 0,9794 & 93,3645 & 6,6355 & 7 & 0,5098 & 0,5298 & 99,4702 \\
8 & 0,9815 & 92,9691 & 7,0309 & 8 & 0,5299 & 0,5404 & 99,4596 \\
9 & 0,9817 & 92,9393 & 7,0607 & 9 & 0,5346 & 0,5490 & 99,4510 \\
10 & 0,9853 & 92,2617 & 7,7382 & 10 & 0,5640 & 0,4961 & 99,5039 \\
\hline
\end{tabular}

The contribution of the new tax revenue variable starts in the second period and so on with values that always increase. That means, if tax revenues continue to rise will increase economic growth. Conversely, the contribution of 
economic growth to tax revenues has begun in the first period until the tenth period. However, the value of the contribution is not significant. This is consistent with the estimation of economic growth towards tax revenue that is not significant in the PVECM model.

Table 12 shows the VDA between economic growth and retribution revenue. The biggest contribution that affects the variable economic growth and retribution revenue is still influenced by itself. The first period, the contribution of retribution revenue was not there to economic growth.

Table 12. VDA of economic growth and retribution revenue

\begin{tabular}{cccccccc}
\hline \multicolumn{3}{c}{ Variance Decomposition of DIFF_GROWTH: } & \multicolumn{5}{c}{ Variance Decomposition of DIFF_RET_INC: } \\
\hline $\begin{array}{c}\text { Perio } \\
\text { d }\end{array}$ & S.E. & $\begin{array}{c}\text { DIFF_GROWT } \\
\text { H DIFF_RET_INC }\end{array}$ & Jeriod & S.E. & $\begin{array}{c}\text { DIFF_GROWT } \\
\text { DIFF_RET_INC }\end{array}$ & H \\
\hline 1 & 0,8427 & 100,0000 & 0,0000 & 1 & 0,8338 & 4,2514 & 95,7486 \\
2 & 0,9612 & 95,3526 & 4,6474 & 2 & 0,9025 & 3,7504 & 96,2496 \\
3 & 0,9748 & 94,7962 & 5,2038 & 3 & 1,1201 & 7,0383 & 92,9617 \\
4 & 1,0311 & 86,2649 & 13,7351 & 4 & 1,1293 & 8,5285 & 91,4715 \\
5 & 1,0390 & 85,1498 & 14,8502 & 5 & 1,1637 & 8,0817 & 91,9183 \\
6 & 1,1020 & 76,6768 & 23,3232 & 6 & 1,2246 & 11,8497 & 88,1504 \\
7 & 1,1041 & 76,7630 & 23,2370 & 7 & 1,2331 & 11,7626 & 88,2374 \\
8 & 1,1220 & 74,5445 & 25,4555 & 8 & 1,2799 & 13,1195 & 86,8805 \\
9 & 1,1370 & 73,9027 & 26,0973 & 9 & 1,3028 & 13,5089 & 86,4911 \\
10 & 1,1425 & 73,2632 & 26,7368 & 10 & 1,3234 & 13,8857 & 86,1143 \\
\hline
\end{tabular}

Source: LHP-LKPD, be trated (BPK 2005-2015)

The second period, the contribution of retribution revenue amounted to 4,6474 and continued to increase until the tenth period of 26,7368 . The contribution of direct economic growth plays a role in influencing retribution revenue in the first period of 4,2514 and continues to increase until the tenth period of 13,8857 . These results confirm that economic growth and retribution revenue affect each other significantly as in the PVECM equation model.

Table 13 shows the VDA between economic growth and regional wealth revenue. The biggest contribution that affects the variables of economic growth and regional wealth revenue is still influenced by itself. In the first period, there was no contribution to regional wealth revenue to economic growth. The second period, the contribution of revenue to regional wealth amounted to 0,0051 and increased to the tenth period of 53,4579 .

The contribution of direct economic growth plays a role in affecting retribution revenue in the first period of 0,0079 and continues to increase until the tenth period of 0,1588 . These results confirm that regional wealth revenue has a significant affect on significant economic growth as in the PVECM equation model. On the contrary, economic growth has no significant effect on regional wealth revenue. 
Table 13. VDA of economic growth and regional wealth revenue

\begin{tabular}{|c|c|c|c|c|c|c|c|}
\hline \multicolumn{4}{|c|}{ Variance Decomposition of DIFF_GROWTH: } & \multicolumn{4}{|c|}{ Variance Decomposition of DIFF_RICH_INC: } \\
\hline Period & S.E. & $\begin{array}{c}\text { DIFF_GROWT } \\
\mathrm{H}\end{array}$ & $\begin{array}{c}\text { DIFF_RICH_IN } \\
C\end{array}$ & Period & S.E. & $\begin{array}{c}\text { DIFF_GROWT } \\
\mathrm{H}\end{array}$ & $\begin{array}{c}\text { DIFF_RICH_IN }_{C} \\
C\end{array}$ \\
\hline 1 & 0,8059 & 100,0000 & 0,0000 & 1 & 0,2295 & 0,0079 & 99,9921 \\
\hline 2 & 0,9538 & 99,9949 & 0,0051 & 2 & 0,2966 & 0,2987 & 99,7013 \\
\hline 3 & 0,9568 & 99,8965 & 0,1035 & 3 & 0,4300 & 0,1953 & 99,8047 \\
\hline 4 & 1,0098 & 89,6958 & 10,3042 & 4 & 0,4510 & 0,1796 & 99,8205 \\
\hline 5 & 1,1097 & 74,6145 & 25,3855 & 5 & 0,4693 & 0,2318 & 99,7682 \\
\hline 6 & 1,2558 & 58,3555 & 41,6446 & 6 & 0,4899 & 0,2247 & 99,7753 \\
\hline 7 & 1,3325 & 51,8363 & 48,1637 & 7 & 0,5192 & 0,2250 & 99,7750 \\
\hline 8 & 1,3658 & 49,3471 & 50,6530 & 8 & 0,6439 & 0,1713 & 99,8287 \\
\hline 9 & 1,3675 & 49,2240 & 50,7760 & 9 & 0,7004 & 0,1461 & 99,8539 \\
\hline 10 & 1,4064 & 46,5421 & 53,4579 & 10 & 0,7639 & 0,1588 & 99,8412 \\
\hline
\end{tabular}

Source: $L H P-L K P D$, be trated (BPK 2005-2015)

Table 14 shows the VDA between economic growth and PAD. The biggest contribution that affects the variables of economic growth and PAD is still affected by itself. In the first period, there was no contribution of PAD to economic growth. The second period, the PAD contribution was 0,7695 and continued to increase until the tenth period of 12,1338.

Table 14. VDA of economic growth and PAD

\begin{tabular}{cccccccc}
\hline \multicolumn{3}{c}{ Variance Decomposition of DIFF_GROWTH: } & \multicolumn{5}{c}{ Variance Decomposition of DIFF_PAD: } \\
\hline Period & S.E. & $\begin{array}{c}\text { DIFF_GROWT } \\
\text { H }\end{array}$ & DIFF_PAD & Period & S.E. & DIFF_GROWT & DIFF_PAD \\
\hline 1 & 0,8016 & 100,0000 & 0,0000 & 1 & 1,6067 & 0,0022 & 99,9978 \\
2 & 0,9571 & 99,2305 & 0,7695 & 2 & 1,7614 & 0,2113 & 99,7887 \\
3 & 0,9602 & 99,1249 & 0,8751 & 3 & 1,7639 & 0,2231 & 99,7769 \\
4 & 0,9614 & 98,8863 & 1,1137 & 4 & 3,1609 & 0,1377 & 99,8623 \\
5 & 0,9652 & 98,2887 & 1,7113 & 5 & 3,9317 & 0,2694 & 99,7306 \\
6 & 0,9695 & 97,6298 & 2,3702 & 6 & 4,0145 & 0,2625 & 99,7375 \\
7 & 0,9747 & 96,6066 & 3,3934 & 7 & 5,7773 & 0,1877 & 99,8123 \\
8 & 0,9787 & 95,8159 & 4,1841 & 8 & 8,1208 & 0,2605 & 99,7395 \\
9 & 0,9959 & 92,5497 & 7,4503 & 9 & 8,7475 & 0,2613 & 99,7387 \\
10 & 1,0221 & 87,8662 & 12,1338 & 10 & 10,6013 & 0,2133 & 99,7867 \\
\hline
\end{tabular}

Source: $L H P-L K P D$, be trated (BPK 2005-2015)

The contribution of direct economic growth played a role in affecting PAD in the first period by 0,0022 and continued to increase until the tenth period of 0,2133 . These results confirm that PAD has a significant effect on significant economic growth as in the PVECM equation model. On the contrary, economic growth has no affect on PAD.

\section{Conclusion}

From the results of this study it can be seen that in fact the regency and city governments in Central Java Province have independent potential from their 
respective regions to increase economic growth in their respective regions. This study obtained the following results.

1. The causality relationship of economic growth and tax revenue occurs in one direction, namely tax revenue affects economic growth, while economic growth does not significantly affect tax revenue. Tax revenue has a significant affect on economic growth with a coefficient of 0,3639 in the first lag and 0,4549 in the second lag.

2. The causality relationship of economic growth and retribution revenue occurs in two directions, namely retribution revenue affects economic growth, as well as economic growth affects retribution revenue. Retribution revenue has a significant affect on economic growth with a coefficient value of 0,7757 in the first lag and 0,4321 in the second lag. Economic growth has a significant affect on retribution revenue with a coefficient of 0,5201 in the first lag and 0,2708 in the second lag.

3. The causality relationship of economic growth and regional wealth revenue occurs in one direction, namely regional wealth revenue affects economic growth, while economic growth does not affect regional wealth revenue. Regional wealth revenue has a significant affect on economic growth with a coefficient value of $-1,1328$ in the first lag and -1,2208 in the second lag.

4. The causality relationship of economic growth and other legitimate revenue does not affect each other.

5. The causality relationship of economic growth and PAD occurs in one direction, namely PAD affects economic growth, while economic growth does not significantly affect PAD. PAD has a significant affect on economic growth with a coefficient of 0,0842 in the first lag but not significant in the second lag.

\subsection{Limitation of Research}

This research has limitations, among others, the data obtained shows a considerable difference in the composition of the PAD structure, especially in the data of other legitimate revenue and tax revenues, but this study does not distinguish the results of estimates between groups of regency and city groups. In the regency area group, the average tax revenue is smaller than the tax revenue in the city area and other legitimate revenue in the regency area is greater than the other legitimate revenue in the city area.

\subsection{Implications}

Regional governments must be careful in maintaining public trust in the management and utilization of taxes in sectors that are able to facilitate the economy of the community. Tax utilization includes spending that can increase economic growth such as capital expenditure (spending on equipment and machinery, infrastructure, increasing labor capacity and public knowledge). In addition, efforts must also be made to spend capital goods to empower local 
entrepreneurs so that they can have an impact on increasing PAD in their respective regions.

Retribution revenue also contributes to a positive affect on economic growth. Therefore, regional governments must optimize and evaluate regional regulations related to taxes and retributions. Regional governments must be able to inventory and force the utilization of regional assets to increase retribution revenues. Regional governments must improve tax and retribution services by building reliable and credible facilities, infrastructure, systems and service administration mechanisms.

Regional wealth revenue has a significant affect on economic growth. That means, the regional government must maximize the management of regional assets and regional wealth. Regional Owned Enterprises must be managed efficiently so as to increase the contribution to PAD. Regional governments need to strengthen the existence of Regional Owned Enterprises that contribute positively and evaluate Regional Owned Enterprises that contribute negatively to PAD. In addition, regional governments need to maintain the linkages and alignments of the management of Regional Owned Enterprises to local communities so that they are able to empower and improve the regional economy.

Other legitimate revenue is not significant in affecting economic growth. Thus, regional governments need to evaluate policies from other legitimate sources of revenue, including interest revenue on deposits, tax penalties, fine fees, compensation claims, sale of regional wealth. Regional governments need to implement policies that are able to reduce other sources of legitimate revenue to be transferred to other PAD sources.

\section{References}

Amri, Khairul. 2017. "Analisis Pertumbuhan Ekonomi dan Ketimpangan Pendapatan: Panel Data 8 Provinsi di Sumatera." Jurnal Ekonomi dan Manajemen Teknologi, Vol. 1, No. 1. 2017, 1-11.

Anicic, Jugoslav, Miloje Jelic, dan Jasminka M. Durovic. 2016. "Local Tax Policy in the Funcion of Development of Municipalities in Serbia." ProcediaSocial and Behavioral Sciences, 221 (2016). 262-269.

Ariutama, I Gede Agus, dan Syahrul. 2014. "Analisis Panel VAR: Tingkat Pendidikan, Tingkat Kesehatan dan Ketimpangan Pendapatan di Indonesia. "Balai Diklat Keuangan Balikpapan.

Arnold, J. 2008. "Do Tax Structures Affect Aggregate Economic Growth? Empirical Evidence From A Panel of OECD Countries." Economics Department, ECO/WKP (2008) 51.

Arsyad, Lincolin. 1997. Ekonomi Pembangunan. Edisi ketiga. Yogyakarta: STIE YKPN. 
Badan Pemeriksa Keuangan. 2006-2016. "Laporan Hasil Pemeriksaan Atas Laporan Keuangan Pemerintah Daerah Kabupaten/Kota Di Jawa Tengah Tahun Anggaran 2005-2015."Jakarta: BPK. Adobe PDF eBook.

Badan Pusat Statistik. 2010. "Produk Regional Bruto Kabupaten/Kota Di Indonesia 2005-2009." Jakarta: BPS. Adobe PDF eBook. 2013. "Produk Regional Bruto Kabupaten/Kota Di Indonesia 2008-2012." Jakarta: BPS. Adobe PDF eBook. 2016. "Produk Regional Bruto Kabupaten/Kota Di Indonesia 2012-2016." Jakarta: BPS. Adobe PDF eBook.

Barro, Robert J. 1990. "Government Spending in a Simple Model of Endogenous Growth." Journal of Political Economy, Vol. 98 (5), 103-125.

Barro, Robert J. 1991. "Economic Growth in a Cross Section of Countries." Quarterly Journal of Economy, Vol. 106, 407-444.

Benos, N. 2005, "Fiscal Policy and Economic Growth: Empirical Evidence from OECD Countries." University of Cyprus Department of Economics Working Paper 2005-01, Vol. 1, no. 51.

Bergh, Andreas, dan Martin Karlsson, 2010. "Government Size and Growth: Accounting for Economic Freedom and Globalization." Public Choice, 2010, Vol. 142 Issue 1, 195-213.

Bernard J.C. and Willet I.S. 1996. "Asymmetric Price Relations in the U.S. Boiler Industry." Journal of Agricultural and Applied Economics, Vol. 28 (2). 279-289.

Bleaney, M., N. Gemmell, and R. Kneller. 2001. "Testing the Endogenous Growth Model: Public Expenditure, Taxation and Growth over the Long-Run." Canadian Journal of Economics, 34, 36-57.

Bodman, Philip, Kelly-Ana Heaton, dan Andrew Hodge. 2009. "Fiscal Decentralization and Economic Growth: A Bayesian Model Averaging Approach. "Macroeconomic Research Group University of Queenslan.

Bujang, Imbarine, Taufik Abd Hakim, dan Ismail Ahmad. 2013. "Tax Structure and Economic Indicator in Developing and High Revenue OECD Countries: Panel Cointegration Analysis." Procedia Economics and Finance, 7. 164-173.

Canavire-Bacarreza G., Martinez-Vazquez, dan Vulovic, V. 2013. "Taxation and Economic Growth in Latin America." IDB WP. No. IDB-WP-431.

Davoodi, H., dan Heng-fu Zou. 1998. "Fiscal Decentralization and Economic Growth: A Cross-Country Study." Journal of Urban Economics, Vol. 43, 244-257.

Desmawati, Ayu, Zamzani, dan Zulgani. 2015. "Pengaruh Pertumbuhan Ekonomi Terhadap Pendapatan Asli Daerah Kabupaten/Kota di Provinsi Jambi." Jurnal Perspektif Pembiyaan dan Pembangunan Daerah, vol. 3, No. 1.

Devkota, K.L. 2014. "Impact of Fiscal Decentralization on Economic Growth in the District of Nepal." International Center for Public Policy. WP 14-20. 
Dorsman. A. Simpson dan Westerman, W. 2012. "Energy Economics and Financial Markets", Springer Science \& Business Media, 12 Oct 2012.

Easterly, W, dan Rebelo, S. 1993. "Fiscal Policy and Economic Growth-An Empirical Investigation." Journal of Monetary Economics, Vol. 32, 417458. http://dx.doi.org/10.3386/w4499

Enders, Walter. 1995. "Applied Econometric Time Series. "New York: John Willey and Sons.

Fadly, Faishal. 2016. "Adakah Pengaruh Pertumbuhan Ekonomi terhadap Pendapatan Asli Daerah." Jurnal Ilmu Ekonomi dan Pembangunan, Vol. 16, No. 2, 2016.

Ferreira, Candida. 2009. "Public Debt and Economics Growth: A Granger Causality Panel Data Approach." Department of Economics Technical University of Lisbon. WP24/2009/DE/UECE.

Folster, Stefan dan Magnus Henrekson. 2001. "Growth Effects of Government Expenditure and Taxation in Rich Countries." European Economic Review, Vol. 45, No. 8. 2001.

Gaspersz, Vincent. 1991. "Uji Heteroskedasitas." Binus University, 20 November 2015. Diakses pada $28 \quad$ September 2018. http://sbm.binus.ac.id/2015/11/20/uji-asumsi-klasik-ujiheteoskedasitas/

Gavriluta (Vatamanu), Anca Florentina dan Florin Oprea. 2017. "Fiscal Decentralization Determinants and Local Economic Development in EU Countries."Eurint 2017.

Gemmel, N, Richard Kneller dan Ismael Sanz, 2013. "Fiscal Decentralization and Economic Growth: Spending Versus Revenue Decentralization". Economic Inquiry, Vol. 51.

Gemmell, N. 2004. "Fiscal Policy in a Growth Framework." Fiscal Policy for Development: Poverty, Reconstruction and Growth." Great Britain: Palgrave Macmillan, 149-176.

Granger, C. 1969. "Investigating Causal Relations by Econometric Models and Cross-spectral Methods." Econometrica, 37 (3): 424-438.

Granger, C. and P. Newbold. 1974. "Spourious Regressions in Econometrics." Journal of Econometrics, Vol. 2, 111-120.

Gujarati, N.D. dan Dawn C. porter. 2009. Basic Econometrics. fifth Edition. Newyork: Mc Graw-Hill Irwin.

Hadi, Y. S. 2003. "Analisis VAR Terhadap Korelasi Antara Pendapatan Nasional dan Investasi Pemerintah Indonesia 1983-2000." Jurnal Keuangan dan Moneter, Vol. 6 No. 2.

Hammond, George W, dan Mehmet S. Tosun. 2009. "The Impact of Local Decentralization on Economic Growth: Evidence from U.S. Countries." Discussion Paper No. 4574. Bonn. 
Hansson, P. and M. Henrekson. 1994. "A New Framework for Testing the Effect of Government Spending on Growth and Productivity." Public Choice, 81, 381-401.

Hendriwiyanto, Guntur, dan Nur Kholis 2015. "Pengaruh Pendapatan Daerah Terhadap Pertumbuhan Ekonomi Dengan Belanja Modal Sebagai Variabel Mediasi." Jurnal IImiah Mahasiswa FEB, Vol. 3.

Hermes, N. and R. Lensink. 2004. "Fiscal Policy and Private Investment in Less Developed Countries." Fiscal Policy for Development: Poverty, Reconstruction and Growth. Great Britain: Palgrave Macmillan, 177-198.

Herwany, Aldrin dan Erie Febrian. 2008. "Cointegration and Causality Analysis on Development Asian Markets For Risk Management and Portfolio Selection." Gadjah Mada International Journal of Business, Vol. 10. No. 3. 285-312.

Hubbard, Glenn, Anthony patrick O'Brien and Matthew Rafferty, (2014). Macroeconomics. Harlow: Pearson Education Limited.

Hurlin, Christophe dan Elena Dumitrescu. 2012. "Testing for Granger Noncausality in Heterogeneous Panels."2012. halshs-00224434v2.

Hurlin, Christophe. 2004. "Testing Granger Causality in Heterogenous Panel Data Models With Fixed Coefficients. "CORE Louvain La Neuve. 2001.

limi, Atsushi. 2005. "Decentralization and Economic Growth Revisited: An Empirical Note." Journal of Urban Economics, Vol. 57 (2005), 449-461.

Kao, C. 1999, "Spurious Regression and Residual-Based Tests for Cointegration in Panel Data." Journal of Econometrics, Vol. 90, 1-44.

Kneller, Richard, Michael F. Bleaney, dan N. Gemmell. 1999. "Fiscal Policy and Growth: Evidence from OECD Countries." Journal of Public Economics, Vol. 74, 171-190.

Lee, Young dan Roger H. Gordon. 2005. "Tax Structure and Economic Growth." Journal of Public Economics, Vol. 89 (2005), 1027-2043.

Levine, R., dan Renelt,D. 1992. "A sensitivity analysis of cross-country growth regressions." American Economic Review, Vol. 82, 942-963.

Lopez, Luciano dan Sylvain Weber. 2017. "Testing for Granger Causality in Panel Data. "University of Neuchatel Institute of Economic Research. WP 1703.

Manek, Marianus dan Rudy Badrudin. 2016. "Pengaruh PAD dan Dana Perimbangan Terhadap Pertumbuhan Ekonomi dan Kemiskinan di Provinsi Nusa Tenggara Timur." Jurnal Telaah Bisnis, Vol. 17, No. 2. 8198.

Mardiasmo, 2002. Akuntansi Srktor Publik. Penerbit Andi, Yogyakarta.

Markova, Gabriela. 2016. "Granger Causality Between Exports and Growth in OECD Countries."Thesis. Jopkoping University. 2016.

Moraru, Camelia dan Roxana Ionita. 2013. "Tax Influence of Taxation on Economic Growth. Econometric Evidence From Romania." Cristian University, Constanta. POSDRU/159/1.5/S/142115. 
Mosley, P. 2000. "Globalisation, Economic Policy and Convergence." World Economy, 23, 613-634.

Muti'ah. 2017. "The Effect of Regional Revenue, Revenue Sharing Fund, General Allocation Fund and Special Allocation Fund on Regional Economic Growth (Empirical Study In the 33 Provinces in Indonesia 2011-2014)." Research Journal of Finance and Accounting, Vol. 8, No. 8.

Mutiara, Dwika Julia. 2015. "Pajak Daerah dan Pengaruhnya Terhadap PDRB di Provinsi Kalimantan Timur." Jurnal Signifikan, Vol. 4, No. 1.

Myles, G. 2009. "Economic Growth and the Role of Taxation." OECD Economic Department, WP No 714. http://dx.doi.org/10.1787/222781828316

Paparas, D. dan Richter C. 2015. "Fiscal Policy and Economic Growth: Empirical Evidence From the European Union." International Network for Economic Research WP2015.06. http://dx.doi.org/10.13140/RG.2.1.1268.1045

Pattawe, Abdul, Djayani Nurdin, Nurhayati Haris, dan Mohammad lqbal Bakri. 2017. "The Effect of Local Revenue and Matching Grant on Capital Expenditures and Implication on Economic Growth in Indonesia." International Journal of Business and Management Invention, Vol. 6, 12-17.

Pedroni, P. 2004, "Panel Cointegration: Asymptotic and Finite Sample Properties of Pooled Time Series Tests With an Application to the PPP Hypothesis." Econometric Theory, 20, 597-625.

Pepinsky, Thomas B, dan Maria M. Wiharja. 2011. "Decentralization and Economic Performance in Indonesia." Journal of East Asian Studies, 2011. http://dx.doi.org/10.1017/S1598240800007372

Psaradakis, Z dan Marian Vavra. 2016. "Portmanteau Test for Linearity and Stationary Time Series". National Bank of Slovakia. WP, April 2016.

Putri, Zuwesty Eka. 2015. "Analisis Pengaruh Pendapatan Asli Daerah (PAD), Dana Alokasi Umum (DAU) dan Inflasi terhadap Pertumbuhan Ekonomi di Kabupaten/Kota Provinsi Jawa Tengah." Jurnal Bisnis dan Manajemen, Vol. 5, No. 2.

Ramsey, J.B. 1969. "Tests for Specification Errors in Classical Linear Least_Squares Regression Analysis." Journal of The Royal Society. Series B (Methodological), Vol. 31, No. 2. pp. 350-371.

Rodriguez-Pose, Andre's dan Anne Kroijer 2009. "Fiscal Decentralization and Economic Growth in Central and Eastern Europe." LSE 'Europe in Question' Discussion Paper Series No. 12/2009.

Rodriguez-Pose, Andre's dan Roberto Ezcurra. 2011. "Is Fiscal Decentralization Harmful for Economic Growth? Evidence From the OECD Countries." Journal of Economic Geography, 11 (2011). pp. 619-643.

Rori, Cindy Febry, Antonius Y. Luntungan, dan Audie O. Niode. 2016. "Analisis Pengaruh Pendapatan Asli Daerah (PAD) Terhadap Pertumbuhan Ekonomi di Provinsi Sulawesi Utara Tahun 2001-2013." Jurnal Berkala IImiah Efisiensi, Vol. 16, No. 12. 
Ruliana, Titin. 2015. "Revenue Independence Of East Kalimantan Province, Indonesia." Journal of Asian Scientific Research, Vol. 5(7), 340-348.

Saidin, Nur Afifah Binti, Abdul Basit, dan Sahibzada Muhammad Hamza. 2016. The Role of Tax on Economic Growth." International Journal of Accounting and Business Management, Vol. 4, No. 2.

Saragih, Juli Panglima. 2003. Desentralisasi Fiskal Dan Keuangan Daerah Dalam Otonomi. Penerbit Ghalia.

Siahaan, Marihot. P. 2013. Pajak dan Retribusi Daerah. Cetakan ketiga. Jakarta: Rajawali Press.

Sims, C.A. 1972. "The Role of Approximate Prior Restriction in Distributed Lag Estimation." Journal of American Statistical Association, Vol. 67, 169175.

Stoilova, Desislava dan N. Patonov. 2013. "An Empirical Evidence For The Impact of Taxation on Economy Growth in the European Union." Tourism and Management Studies, Vol. 3, 1030-103

Stoilova, Desislava. 2016. "Tax Structure and Economic Growth: Evidence From The European Union." Contaduria y Administration, Accounting and Management, Vol. 62 (3), 1041-1057.

Sugiyanto, Catur. 1994. Ekonometrika Terapan. Yogyakarta: BPFE.

Sugiyanto, Catur. 1995. "Pengaruh Pajak Terhadap Pertumbuhan Ekonomi Indonesia." Jurnal Ekonomi dan Keuangan Indonesia, 29-47.

Susanti, Hewi, Mohd. Nur Syechalad dan Abubakar Hamzah. 2017. "Analisis Pengaruh Pertumbuhan Ekonomi dan Pengeluaran Pemerintah Aceh Terhadap PAD Provinsi Aceh Setelah Tsunami." Jurnal Ekonomi dan kebijakan Publik Indonesia, Vol. 4, No. 1.

Szarowska, I. 2013. "Effects of Taxation by Economic Functions on Economic Growth in the European Union." MPRA Paper No. 59781.

Taha, Roshaniza, N. Loganathan, S.R.N. Colombage. 2011. "The Effect of Economic Growth on Taxation Revenue: The Case of a Newly Industrialized Country." International Review of Business Research Papers, Vol. 7. No. 1 319-329.

Takumah, Wisdom dan Bernard Njindan lyke. 2015. "The Links Between Economic Growth and Tax Revenue in Ghana: An Empirical Investigation. "MPRA Paper No. 76010.

Todaro, M.P dan Stephen C. Smith. 2006. Pembangunan Ekonomi. Edisi ke-9. Jakarta: Erlangga.

Triastuti, Dian dan Dudi Pratomo. 2016. "Pengaruh Pertumbuhan Ekonomi, Belanja Modal dan Tingkat Inflasi Terhadap Penerimaan Pajak Daerah (Studi pada Pemerintah Daerah Kota Bandung Periode 2007-2014)." eProceeding of Management, Vol. 3, No.1 April 2016. Page 320.

Widmalm, F. 2001. "Tax Structure and Growth: Are Some Taxes Better than Others?" Public Choice, 107. 199-219. http://dx.doi.org/10.1023/A:1010340017288 
Xing, Jing. 2011. "Does Tax Structure Affect Economic Growth? Empirical Evidence From OECD Countries." Oxford University or Business Taxation. WP 11/20.

Yushkov, Andrey. 2015. "Fiscal decentralization and Regional Economic Growth: Theory, empirics, and the Russian experience." Russian Journal of Economic, Vol. 1, 404-418. 